\title{
Permian A-type granites of the Western Carpathians and Transdanubian regions: products of the Pangea supercontinent breakup
}

\author{
Martin Ondrejka ${ }^{1}$ D $\cdot$ Pavel Uher ${ }^{1} \cdot$ Marián Putiš $^{1}$ (D) $\cdot$ Milan Kohút ${ }^{2}$ (D) Igor Broska ${ }^{2}$ - Alexander Larionov ${ }^{3}$. \\ Ana-Voica Bojar ${ }^{4,5}$ id $\cdot$ Tomáš Sobocký $^{1}$
}

Received: 13 October 2020 / Accepted: 1 June 2021 / Published online: 16 June 2021

(c) The Author(s) 2021

\begin{abstract}
Permian biotite leucogranites to granite porphyries and rhyolites form small intrusions in several Alpine tectonic units in the Western Carpathians and the Pannonian region (Slovakia and Hungary). Their A-type signature is inferred from main- and trace-element geochemistry, with high K, Rb, Y, REE, Zr, Th, Nb, Fe/Mg and Ga/Al, low Al, Mg, Ca, P, Sr, V and strong negative Eu-anomaly. This geochemical signature is further supported by the mineralogy comprising local hypersolvus alkali feldspars, annitic biotite and the presence and composition of HFSE accessory minerals. The $\delta^{18} \mathrm{O}$ values measured for zircon (mean value $8.3 \% \circ \pm 0.36$ ) may be explained by the melting of igneous material of crustal origin and/or mantle basalts which interacted with low-temperature fluids. The in-situ SHRIMP U-Pb isotope dating of zircon from the granites highlights two different periods of magmatic crystallisation and pluton emplacement: the older $281 \pm 3$ Ma Cisuralian age in the southern part, Velence Hills in the Pannonian region (Transdanubian Unit) and younger Guadalupian ages in the northern part, the West-Carpathian area: $262 \pm 4 \mathrm{Ma}$ (Turčok, Gemeric Unit), $267 \pm 2 \mathrm{Ma}$ (Hrončok, Veporic Unit) and $264 \pm 3 \mathrm{Ma}$ (Upohlav, granitic pebbles in Cretaceous conglomerates of the Pieniny Klippen Belt). The 280 to 260-Ma interval is simultaneous with post-orogenic or anorogenic, rift-related and mainly alkaline (A-type) magmatism on the broader European scale. Our study documents a close relationship between the Permian continental rifting and the Neotethyan Meliatic oceanic basin opening in the Middle Triassic. The A-type granites originated from the partial melting of the ancient lower crustal quartzofeldspatic rocks with the possible contribution of meta-basic material from the mantle in an extensional tectonic regime consistent with disintegration of the Pangea supercontinent during the Permian-Triassic period.
\end{abstract}

Keywords A-type granites $\cdot$ Zircon $\cdot$ SHRIMP U-Pb age $\cdot$ Geochemistry $\cdot$ Permian $\cdot$ Western Carpathians $\cdot$ Pannonian area Pangea breakup

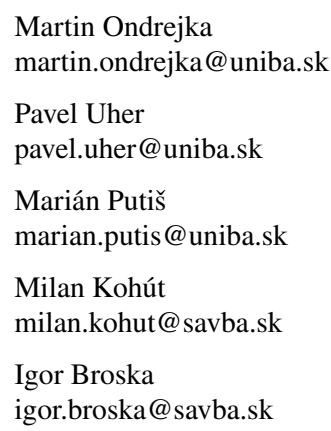

Alexander Larionov alexander.larionov@vsegei.ru

Ana-Voica Bojar ana-voica.bojar@sbg.ac.at

Tomáš Sobocký sobocky1@uniba.sk
1 Department of Mineralogy, Petrology and Economic Geology, Faculty of Natural Sciences, Comenius University Bratislava, Ilkovičova 6, Mlynská dolina, 84215 Bratislava, Slovak Republic

2 Earth Science Institute of the Slovak Academy of Sciences, P.O. BOX 106, Dúbravská cesta 9, 84005 Bratislava, Slovak Republic

3 Russian Geological Research Institute (VSEGEI), Sredny Prospekt 74, 199106 St.-Petersburg, Russia

4 Department of Geology and Geodynamic, Salzburg University, Hellbrunnerstrasse 34, 5020 Salzburg, Austria

5 Study Center of Natural History-Mineralogy, Universalmuseum Joanneum, Weinzöttlstraße 16, 8045 Graz, Austria 


\section{Introduction}

The A-type granites were originally distinguished by Loiselle and Wones (1979) as a specific group of granitic rocks with peculiar chemistry and geotectonic setting (e.g., Bonin 2007, 2008). The A-type granites' origin is generally connected with an extensional regime in the lithosphere (Collins et al. 1982; Whalen et al. 1987; Bonin 2007) and it is related to the geodynamic settings, which are consistent with both crustal and mantle sources (Bonin 2004; Shellnutt and Zhou 2007; Grebennikov 2014; Lu et al. 2020, and references therein). The A-type granites are subdivided into two groups on the basis of trace element abundances, particularly $\mathrm{Y} / \mathrm{Nb}$ ratio (Eby 1992). The $\mathrm{A}_{1}$ group with $\mathrm{Y} / \mathrm{Nb}<1.2$ includes felsic rocks chemically similar to those observed in oceanic islands and continental rifts (ocean island basalts, OIB source). The second $\mathrm{A}_{2}$ group with $\mathrm{Y} / \mathrm{Nb}>1.2$ is proposed to form by several different mechanisms from an island arc or continental margin basalt to the partially melted continental crust sources (Eby 1992). The occurrences of A-type granites can also indicate collided plate suture zones (Balen et al. 2020).

The A-type granites are distinguishable from the S-, Iand M-type genetic groups by major and trace element data. These data include elevated high field strength elements (HFSE: especially Zr, Nb, Ta), REE (except Eu) and F contents, and high $\mathrm{FeO}_{\mathrm{Tot}} / \mathrm{MgO}$ and $\mathrm{Ga} / \mathrm{Al}$ ratios and low $\mathrm{CaO}$ and trace elements compatible with mafic silicate minerals (Co, Sc, Cr, Ni) or feldspars-compatible large-ion lithophile elements (LILE: $\mathrm{Ba}, \mathrm{Sr}$ ) $+\mathrm{Eu}^{2+}$ (Loiselle and Wones 1979; Collins et al. 1982; Whalen et al. 1987; Eby 1990; Bonin 2007; Whalen and Hildebrand 2019; Bonin et al. 2020).

The A-type granites can also be identified by the specific textural and compositional features of rock-forming and accessory minerals, including hypersolvus alkali feldspars, Fe-rich mafic silicates (annite-dominant biotite, locally also alkali amphiboles, pyroxenes and fayalite), crystal morphology and high $\mathrm{Zr} / \mathrm{Hf}$ ratio of zircon and in some cases also by fluorite, topaz, gadolinite, REE-Nb-Ta oxides and other exotic $\mathrm{Zr}$, Ti, Nb and REE minerals (Pupin 1992; Uher and Broska 1996; Bonin et al. 1998, 2020; Bonin 2007; Uher et al. 2009; Breiter et al. 2014 among others).

The A-type granites represent ferroan and anhydrous magmatic suites, typically developed in post-orogenic or anorogenic tectonic environments. Several genetic concepts have been proposed for the origin of their magma, including the processes of anatexis, fractionation and remelting $( \pm$ metasomatism) of various (meta)igneous crustal or mantle sources (e.g., Collins et al. 1982; Clemens et al. 1986; Eby 1990; Creaser et al. 1991; Patiño Douce 1997; Bonin 2004, 2007, 2008 and references therein; Martin 2006; Lu et al. 2020).
Small intrusions of post-Variscan granites and rhyolites with documented A-type affinity have been described within various tectonic units incorporated in Alpine edifice of the Western Carpathian mountain belt in Slovakia and the adjacent Transdanubian Central Range in Hungary. Moreover, analogous granite to rhyolite pebbles to boulders commonly occur as clasts in Cretaceous to Palaeogene flysch conglomerate beds of the Pieniny Klippen Belt. Their petrography, rock-forming and accessory minerals as well as basic geochemical characteristics were investigated by many authors (Buda 1985; Uher and Gregor 1992; Broska et al. 1993; Uher and Marschalko 1993; Uher et al. 1994, 2002a, 2009, 2015, 2018a; b; Uher and Broska 1994, 1996; Petrík et al. 1994, 1995; Buda and Nagy 1995; Broska and Uher 2001; Gyalog and Horváth 2004; Demko and Hraško 2013; Ondrejka et al. 2015, b; Sobocký et al. 2020). Monazite chemical and multi-zircon isotope dating revealed their Permian to Triassic age (Cambel et al. 1977; Uher and Pushkarev 1994; Kotov et al. 1996; Putiš et al. 2000, 2016, 2019a; Finger et al. 2003; Lelkes-Felvári and Klötzli 2004; Radvanec et al. 2009; Vozárová et al. 2009, 2012, 2016; Demko and Hraško 2013; Sobocký et al. 2020; Szemerédi et al. 2020a). In contrast, Neogene mantle-derived $A_{1}$-type granite and syenite xenoliths containing high concentrations of HFSE occur in alkali basalts of northern Pannonian Basin (Slovakia) erupted during Pliocene-Pleistocene extension in Carpathian back-arc (Huraiová et al. 2017, 2019).

However, a complex characterization of this magmatic event using recent petro-chronological data (geochemistry, isotopes and dating) as a base for understanding of their geotectonic role in a broader post-Variscan Alpine-Carpathian domain has been still missing. Consequently, herein we determine major and trace element geochemistry including isotopic data, zircon SHRIMP U-Pb ages and zircon oxygen isotopes of the granites with A-type affinity from the Western Carpathians (Turčok, Hrončok and Upohlav granite) and adjacent Pannonian area (Velence granite) with comparison to related acid volcanic rocks (Fig. 1). Our results contribute to constraining the petrogenetic history of these granitic rocks in the hosting tectonic units during Pangea supercontinent disintegration and Permian post-Variscan/early Alpine geological evolution of Europe.

\section{Geological setting and review of petrographical and mineralogical data}

Several small intrusions of post-Variscan anorogenic biotite leucogranites to granite porphyries with A-type affinity are also known in the Slovak Western Carpathians and the adjacent Transdanubian Central Range in Hungary. These granites are represented by the Turčok, Hrončok and Velence intrusive bodies and the widespread granite pebbles 


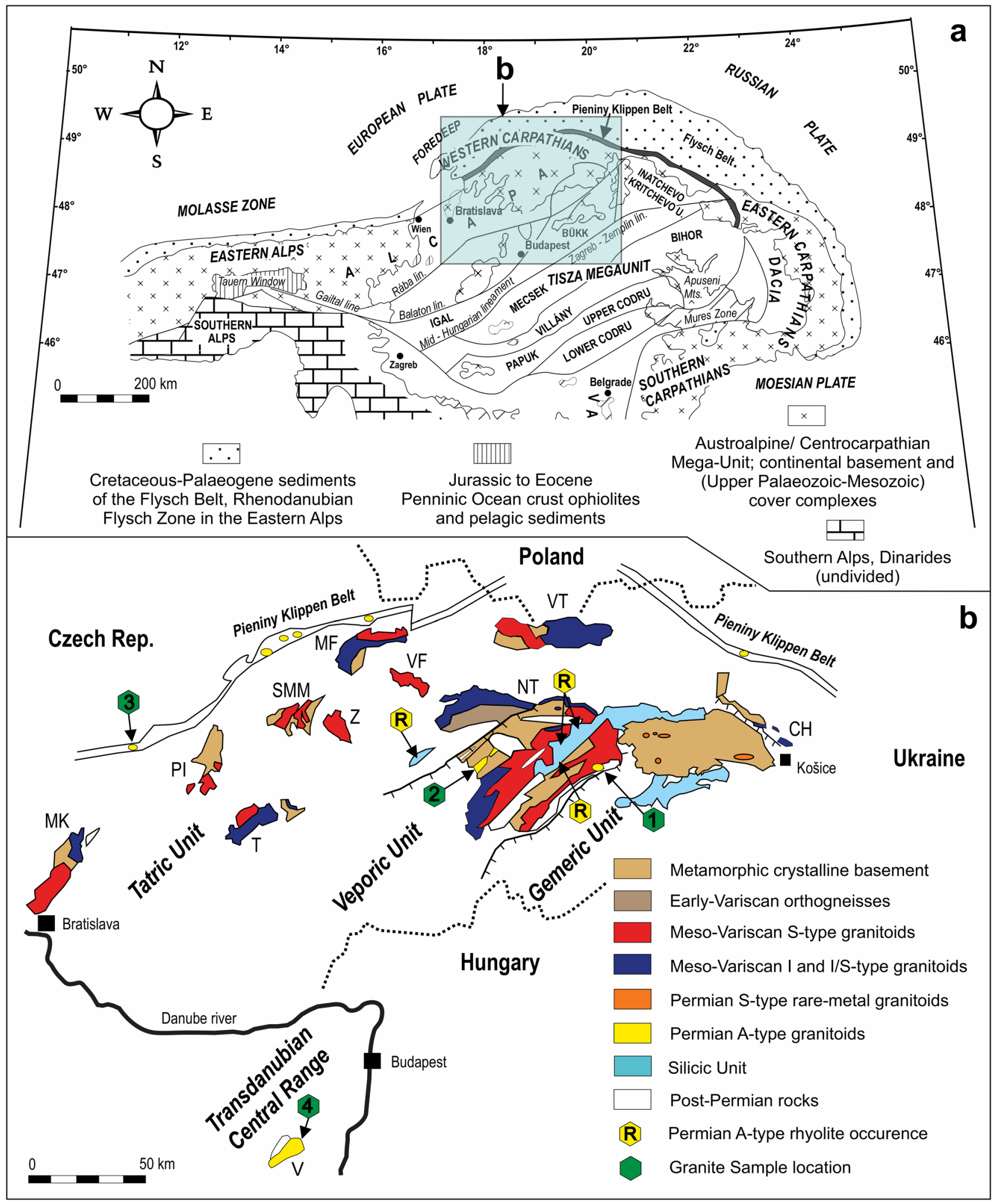

Fig. 1 a Tectonic scheme of the Alpine-Carpathian-Transdanubian Central Range region (modified from Plašienka et al. 1997), b Simplified geological map of the West-Carpathian Palaeozoic crystalline basement and adjacent Transdanubian Central Range region showing the distribution of the main I-, S-, A- and rare-metal S-type granitic rocks. Abbreviations of the mountain ranges are as follows: MK Malé
Karpaty, PI Považský Inovec, $T$ Tribeč, Z Žiar, SMM Suchý, Malá Magura, $M F$ Malá Fatra, $V F$ Vel'ká Fatra, NT Nízke Tatry, VT Vysoké Tatry, $C H$ Čierna Hora, $V$ Velence Hills. Sample location: 1-Turčok, 2-Hrončok, 3-Upohlav, 4-Velence. (modified from Uher and Broska, 1996; Broska and Uher 2001) 
to boulders occur in the Upohlav-type Cretaceous to Palaeogene conglomerates of the Pieniny Klippen Belt (e.g., Uher and Broska 1996; Plašienka et al. 1997). The volcanic rocks of rhyolitic composition and A-type affinity are also widespread in the Western Carpathians (especially in the Veporic, Silicic and Gemeric tectonic units) and the Transdanubian Central Range Unit. The age of the rhyolites in the Silicic Unit were considered as Lower Triassic (e.g., Uher et al. 2002b; Ondrejka et al. 2015). However, recent in situ zircon $\mathrm{U}-\mathrm{Pb}$ dating revealed Permian age of these felsic volcanic rocks (Lelkes-Felvári and Klötzli 2004; Vozárová et al. 2009, 2012, 2016; Putiš et al. 2016; Pelech et al. 2017; Ondrejka et al. 2018b; Szemerédi et al. 2020a).

These intrusions of post-Variscan anorogenic biotite leucogranites to granite porphyries form $\sim 5$ to $20 \mathrm{~km}^{2}$ large intrusive bodies (Fig. 1) along an important intra-Veporic strike-slip zone (Hrončok granite to quartz syenite; Petrík et al. 1995), at the contact of the Veporic and Gemeric units (Turčok granite; Uher and Gregor 1992), or as granitic pebbles to boulders in the Cretaceous flysch sequence in the Pieniny Klippen Belt (Oravic Unit) of the Outer Western Carpathians (Upohlav granitic pebbles-bearing conglomerates; Uher and Marschalko 1993; Uher and Pushkarev, 1994; Uher et al. 1994) and that along the Velence-Balaton lineament in Transdanubian Central Range (Pelsó Unit), NW Hungary (Buda and Nagy 1995; Uher and Broska 1996). These A-type granite bodies, with the exception of the Upohlav and Velence ones, underwent strong Alpine mylonitization (Putiš et al. 1997, 2000; Petrík 2001), and, therefore, the elongated shape of their intrusion bodies could result from an extensional fault-controlled emplacement and later Alpine (Cretaceous) tectonic overprinting (Petrík et al. 1995; Putiš et al. 1997).

The West-Carpathian and Pannonian A-type granites have distinctly different petrographic, mineralogical and geochemical signatures to the predominant Variscan orogen-related S- and I-type, Early Carboniferous granitoids of the West-Carpathian Pre-Alpine basement (e.g., Petrík et al. 1994; Broska and Uher 2001; Kohút and Nabelek 2008). The A-type suite includes leucocratic alkali-feldspar granites to syenogranites with low biotite content (usually 3-7 vol $\%)$, less frequently granite porphyries and very fine-grained aplitic leucogranites, with hypersolvus or transsolvus (Turčok, Upohlav and Hrončok microgranite) to subsolvus alkali feldspar (Velence, Hrončok other varieties) and subhedral to anhedral green to greenish-brown Fe-rich biotite with annite composition (Uher and Broska 1996).

Detailed electron-probe microanalysis (EPMA) study reveals several magmatic to post-magmatic accessory minerals, including REE-Th and Nb-Ta-REE phases, documenting their complex magmatic and post-magmatic evolution (Table 1). Allanite-(Ce) and zircon are the principal early magmatic phases of the hypersolvus to transsolvus granites
Table 1 Summary table of identified accessory mineral assemblages in A-type granites and rhyolites from the West Carpathian-Pannonian region

\begin{tabular}{|c|c|c|c|c|c|}
\hline & Turčok & Upohlav & Velence & Hrončok & rhyolites \\
\hline Zircon & $\mathrm{XX}$ & $\mathrm{XX}$ & $\mathrm{XX}$ & $\mathrm{XX}$ & $\mathrm{XX}$ \\
\hline Fluorapatite & $\mathrm{x}$ & $\mathrm{x}-\mathrm{XX}$ & $\mathrm{x}-\mathrm{XX}$ & $\mathrm{x}-\mathrm{XX}$ & $\mathrm{x}$ \\
\hline Allanite-(Ce) & $\mathrm{x}-\mathrm{XX}$ & $\mathrm{x}-\mathrm{XX}$ & $\mathrm{x}-\mathrm{XX}$ & $\mathrm{x}$ & \\
\hline Ferriallanite-(Ce) & & $\mathrm{x}$ & & & \\
\hline Monazite-(Ce) & $\mathrm{x}$ & $\mathrm{x}$ & $\mathrm{x}$ & $\mathrm{x}-\mathrm{XX}$ & $\mathrm{x}-\mathrm{XX}$ \\
\hline Monazite-(La) & & & $\mathrm{x}$ & & \\
\hline Monazite-(Nd) & & & $\mathrm{x}$ & & \\
\hline Gasparite-(Ce) & & & & & $\mathrm{x}$ \\
\hline Gasparite-(La) & & & & & $\mathrm{x}$ \\
\hline Xenotime-(Y) & $\mathrm{XX}$ & & $\mathrm{x}$ & $\mathrm{x}$ & $\mathrm{x}$ \\
\hline Chernovite-(Y) & & & & & $\mathrm{x}$ \\
\hline Gadolinite-(Y) & $\mathrm{x}$ & & & & \\
\hline Hingganite-(Y) & $\mathrm{x}$ & & & & \\
\hline $\begin{array}{l}\text { Rhabdophane } \\
\text { group }\end{array}$ & $\mathrm{x}$ & $\mathrm{x}$ & $\mathrm{x}$ & & \\
\hline Britholite group & & $\mathrm{x}$ & & & \\
\hline Bastnäsite group & $\mathrm{x}$ & $\mathrm{x}$ & $\mathrm{x}$ & & $\mathrm{x}$ \\
\hline Parisite group & & & & & $\mathrm{x}$ \\
\hline Synchysite group & & $\mathrm{x}$ & & & $\mathrm{x}$ \\
\hline Cerianite-(Ce) & & & & & $\mathrm{x}$ \\
\hline REE-Nb-Ta oxides & $\mathrm{x}$ & & & & \\
\hline Coffinite & & & $\mathrm{x}$ & & \\
\hline Uraninite & & & & $\mathrm{x}$ & \\
\hline Thorite & $\mathrm{x}$ & $\mathrm{x}$ & $\mathrm{x}$ & & $\mathrm{x}$ \\
\hline Thorianite & & $\mathrm{x}$ & $\mathrm{x}$ & & \\
\hline Cheralite & & & $\mathrm{x}$ & & \\
\hline Titanite & & $\mathrm{x}$ & $\mathrm{x}$ & $\mathrm{x}$ & \\
\hline Almandine & & $\mathrm{x}$ & $\mathrm{x}$ & $\mathrm{x}$ & \\
\hline Schorl & $\mathrm{x}$ & $\mathrm{x}$ & $\mathrm{x}$ & & \\
\hline Fayalite & & & $\mathrm{x}$ & & \\
\hline Epidote & $\mathrm{x}$ & $\mathrm{x}$ & $\mathrm{x}$ & $\mathrm{x}$ & \\
\hline Stilpnomelane & & $\mathrm{x}$ & & & \\
\hline Calcite & & $\mathrm{x}$ & & & \\
\hline Baryte & & & & & $\mathrm{x}$ \\
\hline Rutile & $\mathrm{x}$ & $\mathrm{x}$ & $\mathrm{x}$ & $\mathrm{x}$ & $\mathrm{x}$ \\
\hline Pseudorutile & & $\mathrm{x}$ & & & \\
\hline Anatase & & & $\mathrm{x}$ & $\mathrm{x}$ & \\
\hline Ilmenite & $\mathrm{x}$ & $\mathrm{x}-\mathrm{XX}$ & $\mathrm{x}$ & & $\mathrm{x}$ \\
\hline Magnetite & $\mathrm{XX}$ & $\mathrm{x}-\mathrm{XX}$ & $\mathrm{x}$ & $\mathrm{x}$ & $\mathrm{x}$ \\
\hline Hematite & & & & & $\mathrm{x}$ \\
\hline Cassiterite & $\mathrm{x}$ & & & $\mathrm{x}$ & \\
\hline Wolframite series & & & $\mathrm{x}$ & & \\
\hline Pyrite & & $\mathrm{x}$ & $\mathrm{x}-\mathrm{XX}$ & $\mathrm{x}$ & \\
\hline Jamesonite & & & & & $\mathrm{x}$ \\
\hline Molybdenite & & & $\mathrm{x}$ & & \\
\hline Sphalerite & & & $\mathrm{x}$ & & \\
\hline Galena & $\mathrm{x}$ & & $\mathrm{x}$ & & \\
\hline
\end{tabular}

Explanation: $\mathrm{XX}$-common, $\mathrm{X}$-rare with only localised occurrences, $\mathrm{X}-\mathrm{XX}$-rare at some places-common 
(Turčok and Upohlav), and monazite-(Ce) I, zircon I \pm allanite-(Ce) are the typical mineral phases for the subsolvus Hrončok granite (Broska et al. 2012). In addition, xenotime(Y), thorite, zircon II, occasional Y-Be silicates [gadolinite(Y) - hingganite-(Y)], monazite-(Ce) II and REE-Nb-Ta oxide minerals [mainly fergusonite-(Y) and aeschynite/ polycrase-(Y)] are typical late-magmatic to subsolidus accessory phases of the West-Carpathian A-type granites (Uher et al. 2009). Finally, an assemblage of low-temperature to supergene rhabdophane-group minerals, alunite-supergroup minerals, goethite and associated clay minerals were detected in the Velence microgranite (Ondrejka et al. 2018a).

\section{Analytical methods and sample locations}

The multi-element lithogeochemistry of pulp samples has been performed by Bureau Veritas (AcmeLabs) in Vancouver, Canada, by X-ray fluorescence (XRF) for major elements, and the trace and rare earth elements (REE) were determined by inductively coupled plasma atomic emission spectrometry (ICP-AES) and inductively coupled plasma mass spectrometry (ICP-MS). Some older analyses have been performed by University of Ottawa, Ottawa, Memorial University of Newfoundland, St. John's, Canada and IGEM Moscow, Russia. For further details see Petrík et al. (1995), Putiš et al. (2000), Broska and Uher (2001), Uher et al. (2002a, b, 2009) and Broska et al. (2004). All wholerock geochemical plots were performed by the R package GCDkit procedure (Janoušek et al. 2016).

Zircon crystals were extracted from the rocks (Turčok, TU-3; Hrončok, HK-1; Upohlav, BP-1 and Velence VE-1 samples) by standard density and electromagnetic separation routine. The zircon crystals were mounted in epoxy, polished to expose the crystal interiors for analysis and imaged by cathodoluminescence (CL) and back-scattered electrons (BSE) to reveal their internal structure for analytical spot positioning. The highest quality zircon crystals in the studied samples were selected for measurement to avoid fractures, impurities and mineral inclusions. In situ $\mathrm{U}-\mathrm{Pb}$ analysis was performed by SIMS SHRIMP-II apparatus at the Center of Isotopic Research (CIR) at the A.P. Karpinsky Russian Geological Research Institute (VSEGEI), St-Petersburg, Russia.

The results were acquired with a secondary electron multiplier in peak-jumping mode, following the standard procedure of Williams (1998) and Larionov et al. (2004). A primary $\mathrm{O}_{2}^{-}$beam with 2 to $3 \mathrm{nA}$ ion current produced an approximately $25 \times 20 \mu \mathrm{m}$ elliptic analytical crater. Typical mass-resolution at $254 \mathrm{AMU}\left({ }^{238} \mathrm{UO}\right)$ was $\mathrm{M} / \Delta \mathrm{M}>5000$ (1\% valley) and this enabled the resolution of isobaric interference. One-minute rastering over an approximately $65 \times 50 \mu \mathrm{m}$ rectangular area was then employed before each analysis to remove the gold coating and any surface $\mathrm{Pb}$ contamination.
The following ion species were measured in sequence: ${ }^{196}\left(\mathrm{Zr}_{2} \mathrm{O}\right){ }^{204} \mathrm{~Pb}$-background $\left(\sim 204 \mathrm{AMU}-{ }^{206} \mathrm{~Pb}-{ }^{207} \mathrm{~Pb}-{ }^{208}\right.$ $\left.\mathrm{Pb}-{ }^{238} \mathrm{U}-{ }^{248} \mathrm{ThO}-{ }^{254} \mathrm{UO}\right)$ with integration times ranging from 2 to $30 \mathrm{~s}$. Four cycles for each analysed spot were acquired, and each fourth measurement was made on the TEMORA zircon standard (Black et al. 2003) or 91500 as a secondary reference (Wiedenbeck et al. 1995). During the analytical session, 31 spots of TEMORA and 32 spots of 91500 as a concentration standard have been measured. The TEMORA zircons yielded a weighted mean of standard $\mathrm{Pb} / \mathrm{U}$ calibration $0.01320,1 \sigma$ error of mean $\pm 0.71 \%, 1 \sigma$ external spot-to-spot error 2.24\%, MSWD 13.53 (with ${ }^{204} \mathrm{~Pb}$ common lead correction).

The raw data were processed by the SQUID v1.13a software (Ludwig 2005a) and the ISOPLOT/Ex 3.22 (Ludwig 2005b) software with decay constants of Steiger and Jäger (1977) and common lead was corrected using measured ${ }^{204} \mathrm{~Pb} /{ }^{206} \mathrm{~Pb}$ and model values as in Stacey and Kramers (1975), and sample ages of the complex multi-stage evolution were processed by the ISOPLOT "Unmix Ages" tool to distinguish the main age groups.

Concordia diagrams show that almost all measured spots have concordant ages. Discordant results of multiple analyses from the same crystal were then employed to construct Discordia lines. An average of 10 zircon crystals for each rock sample were analysed and the resultant ages with $2 \sigma$ error are shown in Figs. 8, 9, 10, 11, 12.

Analysis of oxygen stable isotope composition of zircon was carried out at the Institute of Earth Sciences, Geology and Paleontology, K.F. University of Graz, Austria. For each sample, up to 1.5 to $2 \mathrm{mg}$ of handpicked selected zircon crystals were heated with a $20 \mathrm{~W} \mathrm{CO}_{2}$ laser following the technique of Sharp (1990). Oxygen was extracted from silicate minerals by fluorination with $\mathrm{BrF}_{5}$ and was measured directly on a Finnigan MAT Delta Plus mass spectrometer without combustion to $\mathrm{CO}_{2}$. Throughout the measurements 1-2 mg of material of several standards were analysed together with the samples. The reproducibility of the measurements was monitored using the garnet standard UWG-2 (Valley et al. 1995; mean value of $5.74 \%$, standard deviation of $0.15 \%$ ) for which a mean value of $5.8 \%$ and a standard deviation of $0.15 \%$ were obtained. Measurements on NBS 30 biotite gave an average value of $5.04 \%$ and a standard deviation of $0.2 \%$ (accepted value $5.1 \%$, standard deviation $0.2 \%$ ). The data are given on the VSMOW scale.

Locations of granite samples investigated by $\mathrm{U}-\mathrm{Pb}$ SHRIMP and O isotope methods of zircon are given in Table 2. 
Table 2 Summary table of investigated rock samples, locations and measurements obtained

\begin{tabular}{|c|c|c|c|c|c|c|}
\hline Granite body & Sample & Rock & Location & GPS & SHRIMP U-Pb & $\begin{array}{l}\text { Oxygen } \\
\text { isotopes }\end{array}$ \\
\hline \multirow[t]{2}{*}{ Turčok } & TU-1 & Biotite Leucogranite & $\begin{array}{l}\text { Štyri Chotáre Hill } \\
(648 \mathrm{~m}), \sim 1.5 \mathrm{~km} \text { of Turčok } \\
\text { village near Revúca, Slovak } \\
\text { Ore Mts., Slovakia }\end{array}$ & $48^{\circ} 38^{\prime} 28^{\prime \prime} \mathrm{N} ; 20^{\circ} 10^{\prime} 14^{\prime \prime} \mathrm{E}$ & No & Yes \\
\hline & TU-3 & Biotite Leucogranite & Identical with TU-1 & $48^{\circ} 38^{\prime} 28^{\prime \prime} \mathrm{N} ; 20^{\circ} 10^{\prime} 14^{\prime \prime} \mathrm{E}$ & Yes & No \\
\hline \multirow[t]{2}{*}{ Hrončok } & HK-1 & Muscovite-Biotite granite & $\begin{array}{l}\text { Kamenistá Valley, } 1.9 \text { km } \\
\text { WSW of Zákl’uky Hill } \\
(1012 \text { m), Slovak Ore Mts., } \\
\text { Slovakia }\end{array}$ & $48^{\circ} 41^{\prime} 38^{\prime \prime} \mathrm{N} ; 19^{\circ} 32^{\prime} 6^{\prime \prime} \mathrm{E}$ & Yes & No \\
\hline & ZK-26 & Muscovite-Biotite granite & $\begin{array}{l}\text { Identical with HK-1. For futher } \\
\text { details, see Macek et al. (1982) }\end{array}$ & $48^{\circ} 41^{\prime} 38^{\prime \prime} \mathrm{N} ; 19^{\circ} 32^{\prime} 6^{\prime \prime} \mathrm{E}$ & No & Yes \\
\hline \multirow[t]{4}{*}{ Upohlav } & BP-1 & Biotite leucogranite & $\begin{array}{l}\sim 50 \mathrm{~m} / 350^{\circ} \mathrm{N} \text { of Starý Hrad Hill } \\
(454 \mathrm{~m}), \text { Podbranč village near } \\
\text { Senica, Slovakia }\end{array}$ & $48^{\circ} 43^{\prime} 43^{\prime \prime} \mathrm{N} ; 17^{\circ} 28^{\prime} 55^{\prime \prime} \mathrm{E}$ & Yes & Yes \\
\hline & BP-6.2 & Biotite leucogranite & $\begin{array}{l}1.3 \mathrm{~km} / 129^{\circ} \text { of Hora }(626 \mathrm{~m}) \\
\text { Považský Chlmec, Žilina, } \\
\text { Slovakia }\end{array}$ & $49^{\circ} 14^{\prime} 31^{\prime \prime} \mathrm{N} ; 18^{\circ} 44^{\prime} 08^{\prime \prime} \mathrm{E}$ & No & Yes \\
\hline & BP-35 & Biotite leucogranite & $\begin{array}{l}600 \mathrm{~m} / 212^{\circ} \text { of Holís }(583 \mathrm{~m}), \\
\text { Nimnica, Slovakia }\end{array}$ & $49^{\circ} 08^{\prime} 31^{\prime \prime} \mathrm{N} ; 18^{\circ} 21^{\prime} 50^{\prime \prime} \mathrm{E}$ & No & Yes \\
\hline & BP-38 & Biotite leucogranite & $\begin{array}{l}2.1 \mathrm{~km} / 194^{\circ} \text { of Havraní vrch } \\
(419 \mathrm{~m}) \text {, Prosačov, Slovakia }\end{array}$ & $49^{\circ} 02^{\prime} 60^{\prime \prime} \mathrm{N} ; 21^{\circ} 32^{\prime} 21^{\prime \prime} \mathrm{E}$ & No & Yes \\
\hline \multirow[t]{3}{*}{ Velence } & VE-1 & Biotite leucogranodiorite & $\begin{array}{l}\text { Outcrops on the M7 high- } \\
\text { way, 300 m N of Mészeg Hill } \\
(154 \mathrm{~m}), 1.5 \mathrm{~km} \text { SW of Sukoró } \\
\text { village near Székesfehérvár, } \\
\text { Velence Mts., Hungary }\end{array}$ & $47^{\circ} 13^{\prime} 53^{\prime \prime} \mathrm{N} ; 18^{\circ} 34^{\prime} 59^{\prime \prime} \mathrm{E}$ & Yes & Yes \\
\hline & VE-2 & Biotite leucotonalite & $\begin{array}{l}\text { Fine-grained magmatic enclaves } \\
\text { in VE-1 }\end{array}$ & $47^{\circ} 13^{\prime} 53^{\prime \prime} \mathrm{N} ; 18^{\circ} 34^{\prime} 59^{\prime \prime} \mathrm{E}$ & No & Yes \\
\hline & VE-3 & Biotite monzogranite & $\begin{array}{l}\text { Weathered rock, Aranybulla } \\
\text { quarry, Székesfehérvár, Hun- } \\
\text { gary }\end{array}$ & $47^{\circ} 12^{\prime} 24^{\prime \prime} \mathrm{N} ; 18^{\circ} 28^{\prime} 53^{\prime \prime} \mathrm{E}$ & No & Yes \\
\hline
\end{tabular}

\section{Results}

\section{Whole-rock major and trace element geochemistry}

The representative results of the whole-rock chemical analyses are given in Table 3. All samples except one (Hrončok quartz syenite) plot into the granite and alkali granite fields (Fig. 2) of the R1-R2 classification diagram (de La Roche et al. 1980). Generally, the investigated granites have high $\mathrm{SiO}_{2}$; average values (av): $75.6 \mathrm{wt} \%$ for Turčok; $72.8 \mathrm{wt} \%$ for Hrončok; $72.7 \mathrm{wt} \%$ for Upohlav and $71.7 \mathrm{wt} \%$ for Velence, $\mathrm{Na}_{2} \mathrm{O}+\mathrm{K}_{2} \mathrm{O}-\mathrm{CaO}>5.7$ (Fig. 3a), $\mathrm{K}_{2} \mathrm{O} / \mathrm{Na}_{2} \mathrm{O}>1.2$ (except Turčok $<0.6$, due to subsolidus albitization and partial loss of $\mathrm{K}, \mathrm{Rb}$ ), and low $\mathrm{TiO}_{2}(0.05-0.6 \mathrm{wt} \%$ ), $\mathrm{CaO}$ (av $0.6 \mathrm{wt} \%$ ), $\mathrm{P}_{2} \mathrm{O}_{5}(0.01-0.2 \mathrm{wt} \%), \mathrm{MgO}$ (av $0.5 \mathrm{wt} \%$ ) and $\mathrm{FeO}_{\text {tot }}$ (av 2.9 wt $\%)$, but relatively high $\mathrm{FeO}_{\text {tot }} /\left(\mathrm{FeO}_{\text {tot }}+\mathrm{MgO}\right)$ av $=0.81$ (Fig. 3b). Their A/CNK and $\mathrm{A} / \mathrm{NK}$ ratios range from 0.8 to 1.6 and 0.9 to 1.6 , respectively, and correspond to dominantly peraluminous, but also metaluminous (Upohlav and Hrončok, 4 samples) and even peralkaline (Upohlav,
3 samples). The majority of granite samples cluster at $\mathrm{A} /$ $\mathrm{CNK}=1.0-1.3$ (Fig. 4).

Trace-element geochemistry shows an enrichment in Rb (av 202 ppm, except Turčok, av 30 ppm), Zr (Hrončok av 115 ppm, Velence av 180 ppm, Upohlav av 290 ppm, Turčok av 415 ppm), Hf (av 5.7 ppm), Nb (av 17 ppm), Ta (av 1.4 ppm), Ga (av 22 ppm), total REE (av 200 ppm) and depletion in $\mathrm{Sr}$ (av $76 \mathrm{ppm}$ ) and $\mathrm{V}$ (av $14 \mathrm{ppm}$ ) as well as elevated $\mathrm{Y} / \mathrm{Nb}>1.2, \mathrm{Th} / \mathrm{U}(\mathrm{av} \sim 4.9), \mathrm{Rb} / \mathrm{Sr}(\mathrm{av} \sim 2.1)$ and $10000 \mathrm{Ga} / \mathrm{Al}(\mathrm{av} \sim 3.0)$ ratios (Fig. 5, 6). In the chondrite-normalized REE distribution patterns (Fig. 7), the granite samples exhibit enrichment of light rare earth elements (LREE) and distinct negative Eu anomalies $\left(\mathrm{Eu}_{\mathrm{N}} /\right.$ $\left.\mathrm{Eu}^{*}{ }_{\mathrm{N}}=0.03-0.60\right)$.

\section{Zircon characterization}

Primary magmatic zircon belongs to the most common accessory minerals in the investigated A-type granites. The zircon crystals are usually transparent and most 
Table 3 Chemical analyses of representative whole-rock samples from A-type granites

\begin{tabular}{|c|c|c|c|c|c|c|c|c|}
\hline \multirow{2}{*}{$\begin{array}{l}\text { Granite body } \\
\text { Sample }\end{array}$} & \multicolumn{2}{|l|}{ Turčok } & \multicolumn{2}{|c|}{ Hrončok } & \multicolumn{2}{|l|}{ Upohlav } & \multicolumn{2}{|c|}{ Velence } \\
\hline & ZK-16 & Av & VG-89 & Av & BP-14.2 & $\mathrm{Av}$ & VE-2 & $\mathrm{Av}$ \\
\hline $\mathrm{SiO}_{2}(\mathrm{wt} \%)$ & 75.76 & 75.62 & 70.58 & 72.77 & 73.86 & 72.71 & 67.28 & 71.66 \\
\hline $\mathrm{TiO}_{2}$ & 0.17 & 0.18 & 0.32 & 0.25 & 0.15 & 0.22 & 0.41 & 0.35 \\
\hline $\mathrm{Al}_{2} \mathrm{O}_{3}$ & 12.55 & 13.56 & 14.37 & 13.70 & 13.13 & 13.52 & 16.23 & 14.19 \\
\hline $\mathrm{Fe}_{2} \mathrm{O}_{3}$ & 2.09 & 1.31 & 2.75 & 1.87 & 1.87 & 2.17 & 3.91 & 1.99 \\
\hline $\mathrm{MnO}$ & 0.02 & 0.01 & 0.07 & 0.07 & 0.02 & 0.03 & 0.09 & 0.05 \\
\hline $\mathrm{MgO}$ & 0.45 & 0.41 & 0.54 & 0.54 & 0.14 & 0.48 & 0.74 & 0.57 \\
\hline $\mathrm{CaO}$ & 0.38 & 0.16 & 1.50 & 0.71 & 0.53 & 0.88 & 1.36 & 0.76 \\
\hline $\mathrm{Na}_{2} \mathrm{O}$ & 4.75 & 6.60 & 3.29 & 3.69 & 3.75 & 3.55 & 4.07 & 3.58 \\
\hline $\mathrm{K}_{2} \mathrm{O}$ & 2.79 & 1.08 & 4.61 & 4.55 & 5.06 & 4.80 & 4.30 & 4.48 \\
\hline $\mathrm{P}_{2} \mathrm{O}_{5}$ & 0.02 & 0.03 & 0.12 & 0.10 & 0.03 & 0.09 & 0.12 & 0.08 \\
\hline L.O.I & 1.50 & 1.37 & n.a & 1.29 & n.a & 1.32 & n.a & 1.64 \\
\hline Total & 100.48 & 100.32 & 98.14 & 99.55 & 98.54 & 99.75 & 98.51 & 100.59 \\
\hline $\mathrm{FeO}_{\text {tot }} /\left(\mathrm{FeO}_{\mathrm{tot}}+\mathrm{MgO}\right)$ & 0.81 & 0.80 & 0.82 & 0.79 & 0.92 & 0.83 & 0.83 & 0.82 \\
\hline $\mathrm{A} / \mathrm{CNK}$ & 1.09 & 1.10 & 1.09 & 1.11 & 1.04 & 1.07 & 1.17 & 1.17 \\
\hline $\mathrm{A} / \mathrm{NK}$ & 1.16 & 1.13 & 1.38 & 1.25 & 1.13 & 1.23 & 1.43 & 1.32 \\
\hline $\mathrm{V}(\mathrm{ppm})$ & 1 & 2.7 & 21 & 18.4 & 5 & 9.5 & 26 & 24.1 \\
\hline $\mathrm{Cr}$ & 11 & 15.3 & 15 & 18.3 & 21 & 10.9 & 13 & 9.5 \\
\hline $\mathrm{Ga}$ & 22 & 28.5 & n.a & 21.7 & 19.4 & 19.6 & n.a & 18.8 \\
\hline $\mathrm{Zr}$ & 410 & 416 & 181 & 114 & 262 & 289 & 320 & 181 \\
\hline $\mathrm{Hf}$ & 9 & 8.6 & 4.6 & 3.5 & 6.1 & 6.7 & 7.7 & 4.1 \\
\hline $\mathrm{Nb}$ & 18 & 19 & 16 & 16 & 20 & 16 & 21 & 15 \\
\hline $\mathrm{Ta}$ & 1.4 & 1.2 & 1.5 & 1.6 & 2.1 & 1.3 & 1.8 & 1.3 \\
\hline $\mathrm{Rb}$ & 66 & 29 & 196 & 211 & 212 & 179 & 260 & 216 \\
\hline $\mathrm{Sr}$ & 16 & 23 & 133 & 68 & 24 & 42 & 246 & 119 \\
\hline $\mathrm{Ba}$ & 481 & 187 & 420 & 330 & 453 & 720 & 472 & 378 \\
\hline Co & 2 & 4 & 3 & 6 & 28 & 8 & 5 & 4 \\
\hline $\mathrm{Ni}$ & 2 & 3 & 7 & 9 & 0 & 6 & $\operatorname{tr}$ & 4 \\
\hline $\mathrm{Zn}$ & 9 & 9 & 58 & 34 & 60 & 55 & 85 & 61 \\
\hline $\mathrm{Pb}$ & 51.0 & 32.5 & 17.0 & 17.0 & 17.0 & 17.7 & 31.0 & 29.6 \\
\hline Th & 12.0 & 12.7 & 15.0 & 14.5 & 20.0 & 19.1 & 28.1 & 21.4 \\
\hline $\mathrm{U}$ & 5.0 & 5.0 & 1.0 & 3.9 & 1.0 & 2.0 & 13.0 & 5.3 \\
\hline $\mathrm{Y}$ & 79.3 & 73.6 & 28.5 & 26.4 & 40.6 & 33.0 & 58.6 & 33.2 \\
\hline $\mathrm{La}$ & 49.9 & 44.2 & 34.1 & 18.2 & 54.0 & 52.0 & 43.9 & 27.7 \\
\hline $\mathrm{Ce}$ & 113.3 & 102.5 & 69.3 & 38.2 & 109.9 & 109.5 & 88.5 & 58.7 \\
\hline $\operatorname{Pr}$ & 14.6 & 12.8 & 8.1 & 4.6 & 13.1 & 13.2 & 10.5 & 6.7 \\
\hline $\mathrm{Nd}$ & 62.2 & 53.5 & 30.6 & 17.6 & 48.8 & 49.7 & 42.4 & 25.9 \\
\hline $\mathrm{Sm}$ & 16.1 & 12.7 & 6.4 & 4.4 & 9.4 & 9.6 & 10.3 & 5.8 \\
\hline $\mathrm{Eu}$ & 2.7 & 2.1 & 0.9 & 0.5 & 0.9 & 1.1 & 1.1 & 0.8 \\
\hline $\mathrm{Gd}$ & 17.0 & 12.7 & 5.4 & 4.5 & 7.9 & 7.9 & 10.9 & 5.6 \\
\hline $\mathrm{Tb}$ & 2.7 & 2.2 & 0.9 & 0.8 & 1.2 & 1.2 & 1.7 & 0.9 \\
\hline Dy & 16.7 & 13.9 & 5.3 & 4.9 & 7.7 & 7.0 & 10.9 & 5.8 \\
\hline Ho & 3.2 & 2.9 & 1.1 & 1.0 & 1.5 & 1.4 & 2.2 & 1.2 \\
\hline $\mathrm{Er}$ & 8.9 & 8.5 & 3.0 & 3.0 & 4.3 & 4.0 & 6.4 & 3.5 \\
\hline $\mathrm{Tm}$ & 1.3 & 1.3 & 0.4 & 0.5 & 0.6 & 0.6 & 1.0 & 0.5 \\
\hline $\mathrm{Yb}$ & 8.7 & 8.5 & 2.8 & 3.0 & 4.0 & 3.5 & 6.5 & 3.6 \\
\hline $\mathrm{Lu}$ & 1.3 & 1.3 & 0.4 & 0.5 & 0.6 & 0.6 & 1.0 & 0.6 \\
\hline $10000 \mathrm{Ga} / \mathrm{Al}$ & 3.3 & 4.0 & n.a & 3.0 & 2.8 & 2.7 & n.a & 2.5 \\
\hline
\end{tabular}

Turčok: deformed Bt-leucogranite (ZK-16, Uher et al. 2009); Hrončok: massive, medium-grained Bt-monzogranite (VG-89); Upohlav: granite-granodiorite (BP-14.2); Velence: Bt-leucotonalite (VE-2)

$A v$ average composition, $n . a$. not analysed, $\operatorname{tr}$ traces 


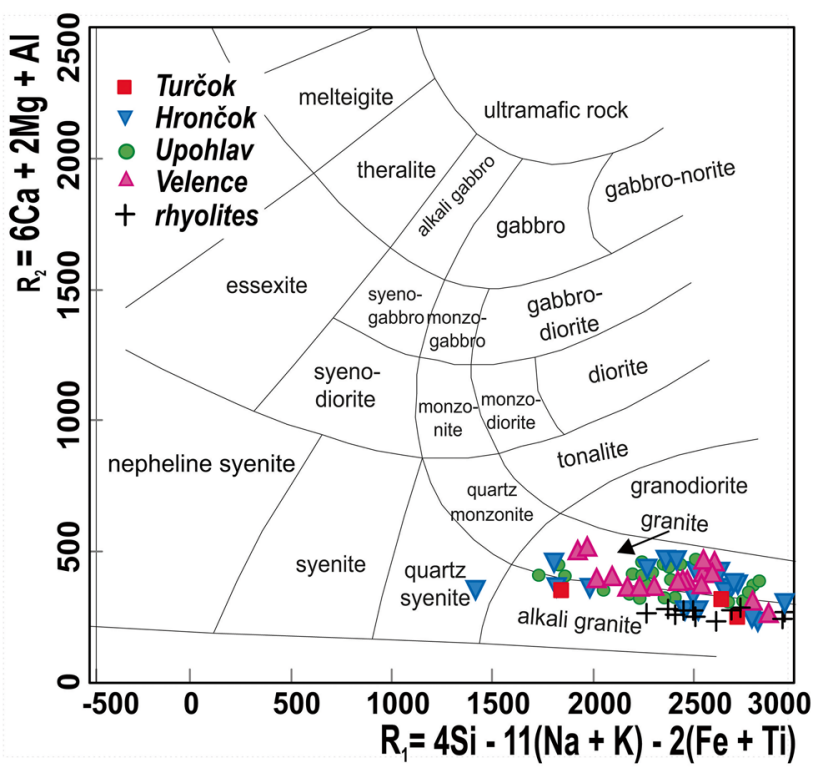

Fig. 2 Binary plot of R1-R2 (de la Roche et al. 1980). R1=4Si $-11(\mathrm{Na}+\mathrm{K})-2(\mathrm{Fe}+\mathrm{Ti}) ; \mathrm{R} 2=6 \mathrm{Ca}+2 \mathrm{Mg}+\mathrm{Al}$ (milications)

are $\sim 50-300 \mu \mathrm{m}$ in length. Euhedral zircon crystals have predominantly $\mathrm{P}_{4}-\mathrm{P}_{5}$ and $\mathrm{D}$ (sub)type morphology according to the typology classification (Pupin 1980). While the investigated zircon crystals' internal texture comprises magmatic fine oscillatory and/or sector zoning, irregular and most likely late-magmatic to subsolidus marginal domains, are present to a lesser extent. Some zircon crystals also contain small round inherited xenocrystic cores (Fig. 8).

\section{SHRIMP zircon $\mathrm{U}-\mathrm{Pb}$ ages}

A total of 38 spot analyses were performed on the A-type granite zircon crystals: 8 from Turčok (TU-3 sample), 10 from Hrončok (HK-1), 10 from Upohlav (BP-1) and 10 from Velence (VE-1). Table 4 summarizes all isotope analytical data. The $f_{206}$ values (proportions of common ${ }^{206} \mathrm{~Pb}$ in the total measured ${ }^{206} \mathrm{~Pb}$ ) ranged from 0.17 to $2.47 \%$ (TU-3), $0.11-1.45 \%$ (HK-1), 0.00-8.19\% (BP-1) and 0.00-24.29\% (VE-1).

Zircon from the Turčok granite (TU-3) contains 250-580 ppm U and 70-280 ppm Th concentrations providing $0.29-0.66 \mathrm{Th} / \mathrm{U}$ ratio. These $\mathrm{U}-\mathrm{Pb}$ isotope analyses are concordant within the analytical error and yield $262 \pm 4 \mathrm{Ma}$ Concordia age (MSWD of concordance $=0.13)$ (Fig. 9).

The Hrončok granite zircon (HK-1) revealed 200-1100 ppm U and Th $=60-390 \mathrm{ppm}$ Th, resulting in the relatively wide $\mathrm{Th} / \mathrm{U}$ ratio between 0.15 and 0.90 . Their $\mathrm{U}-\mathrm{Pb}$ isotope analyses are concordant within the analytical error, yielding a Concordia age of $267 \pm 2 \mathrm{Ma}$ (MSWD of concordance $=0.70)$ (Fig. 10). Here, the HK-6-1 spot yielded a clearly older age of $632 \pm 8 \mathrm{Ma}(1 \sigma)$ than most of the population, and the CL image highlighted a clear small resorbed core, thus indicating potential inheritance. The remaining nine zircons are mostly euhedral crystals with well-developed concentric or convolute irregular zoning.

Zircon from the Upohlav granite (BP-1) showed $130-1570 \mathrm{U}$ and $60-1320 \mathrm{ppm} \mathrm{Th}$, and $\mathrm{Th} / \mathrm{U}=0.40-0.94$. Their U-Pb isotope analyses had $264 \pm 3 \mathrm{Ma}$ concordant ages (MSWD of concordance $=0.013)$ (Fig. 11).
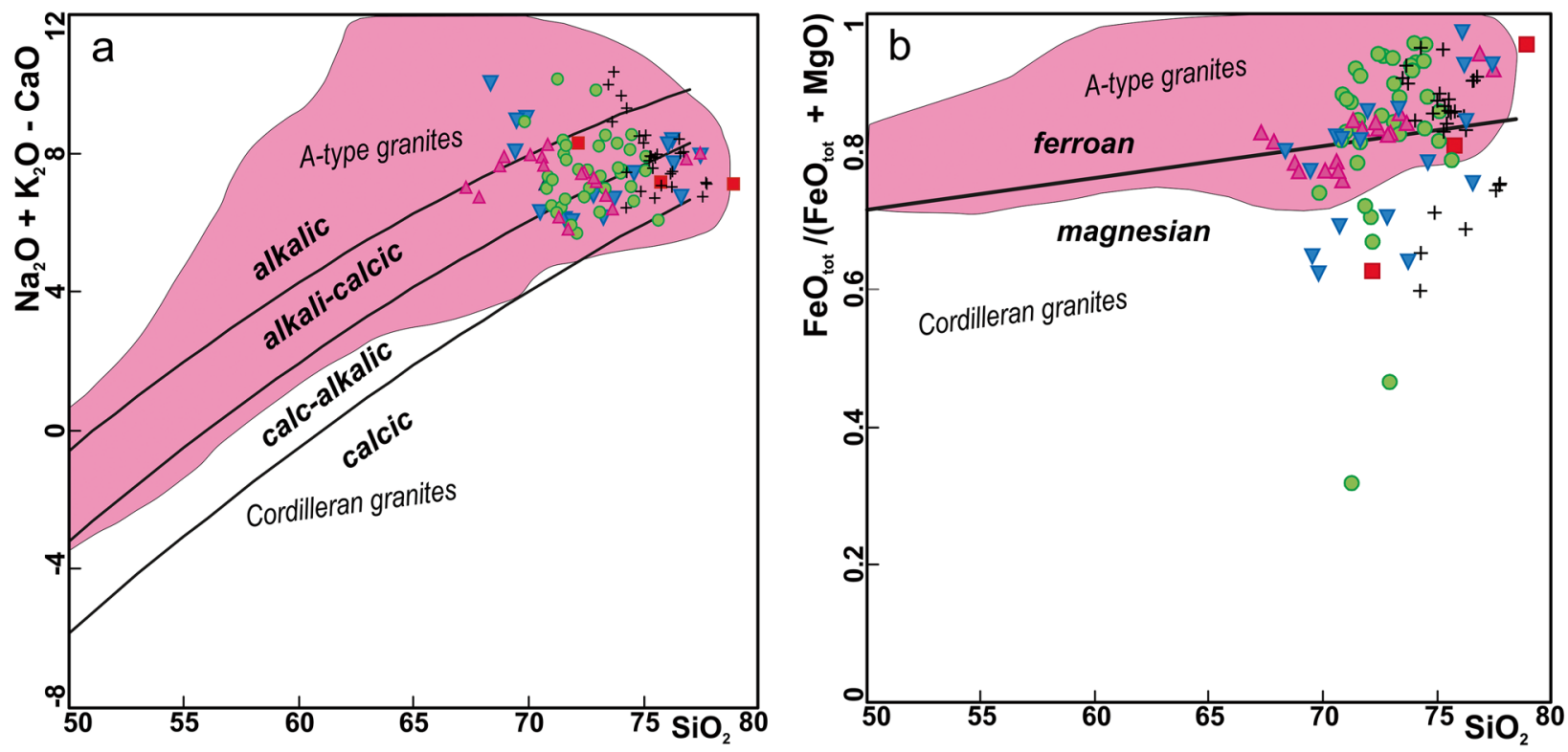

Fig. 3 a Binary plot $\mathrm{SiO}_{2}$ vs. $\mathrm{Na}_{2} \mathrm{O}+\mathrm{K}_{2} \mathrm{O}-\mathrm{CaO}, \mathbf{b ~} \mathrm{SiO}_{2}$ vs. $\mathrm{FeO}_{\text {tot }} /\left(\mathrm{FeO}_{\text {tot }}+\mathrm{MgO}\right)(\mathrm{a}, \mathrm{b}$ after Frost et al. 2001). Same symbols as in Fig. 2 


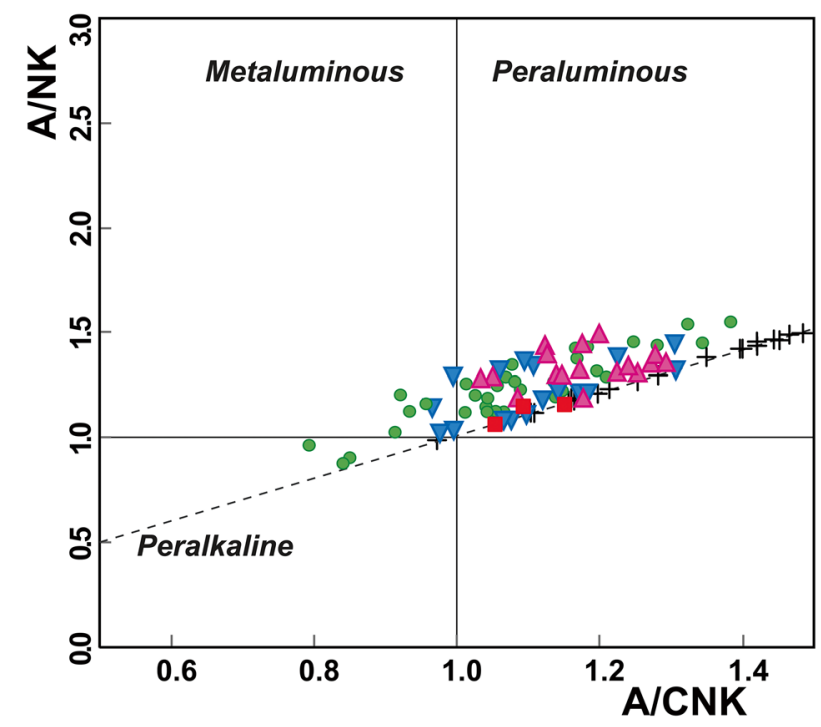

Fig. 4 Binary plot of $\mathrm{A} / \mathrm{CNK}$ vs. $\mathrm{A} / \mathrm{NK}$. $\mathrm{A} / \mathrm{CNK}=\mathrm{Al}_{2} \mathrm{O}_{3}$ / $\left(\mathrm{CaO}+\mathrm{Na}_{2} \mathrm{O}+\mathrm{K}_{2} \mathrm{O}\right) \quad \mathrm{A} / \mathrm{NK}=\mathrm{Al}_{2} \mathrm{O}_{3} /\left(\mathrm{Na}_{2} \mathrm{O}+\mathrm{K}_{2} \mathrm{O}\right)$ (mol. \%). Same symbols as in Fig. 2

The Velence granite zircon (VE-1) contains 180-890 ppm $\mathrm{U}$ and $110-480 \mathrm{ppm}$ Th, providing a relatively wide $\mathrm{Th} / \mathrm{U}$ ratio: $0.40-1.21$. Here, the 4.1 and 5.1 spots situated in partly resorbed cores yielded clearly older $654 \pm 10$ and $400 \pm 14$ Ma ages $(1 \sigma)$, thus indicating potential inheritance.
The remaining eight analyses were concordant within the analytical error, yielding 281 \pm 3 Ma Concordia age (MSWD of concordance $=0.078$ ) (Fig. 12).

\section{Oxygen stable isotopes in zircon}

A total of nine handpicked concentrates of transparent zircon crystals were analysed for $\delta^{18} \mathrm{O}$ values, the results being listed in Table 5 and plotted against $\mathrm{SiO}_{2}$ in Fig. 13. One sample from the Turčok granite shows a value of $8.3 \%$, one sample from the Hrončok shows $8.1 \%$, four samples from Upohlav range between 7.5 and $8.5 \%$ and three samples from the Velence range between 8.0 and $8.5 \%$.

\section{Discussion}

\section{Geochemical and mineralogical characteristics}

The investigated granites reveal geochemical and mineralogical characteristics which clearly reflect their A-type affinity based on those previously published (e.g., Uher et al. 1994; Uher and Broska 1994, 1996; Broska and Uher 2001) and our recent data as summarized in the following items:

(i) Leucocratic and dominantly peraluminous, but also metaluminous, and even peralkaline character with high

b

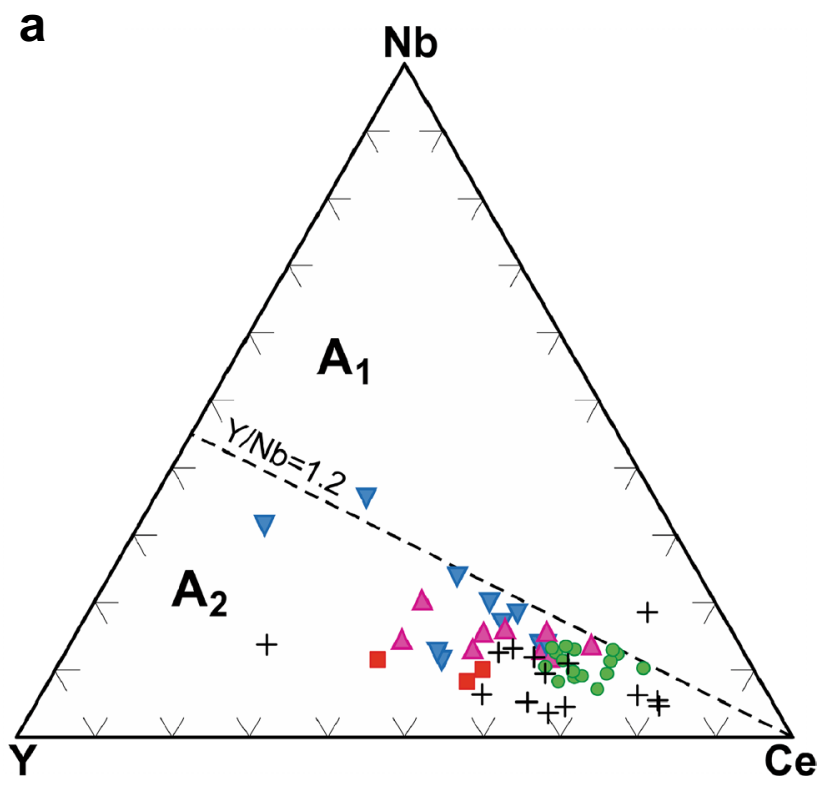

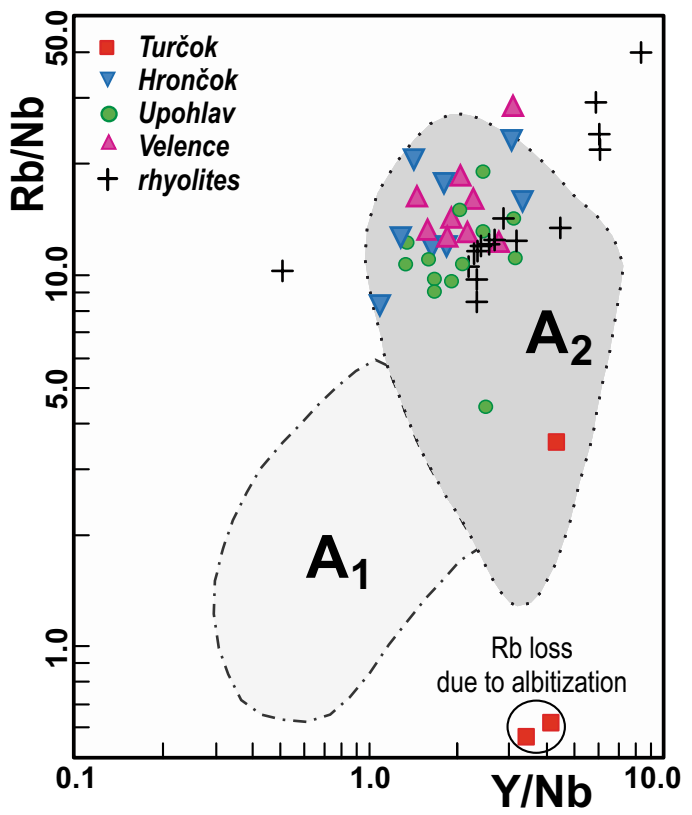

Fig. 5 a Ternary plot of Y-Nb-Ce. Dashed line corresponds to Y/Nb ratio of 1.2, b Binary plot of Y/Nb vs. Rb/Nb (a, b after Eby 1992). Same symbols as in Fig. 2 


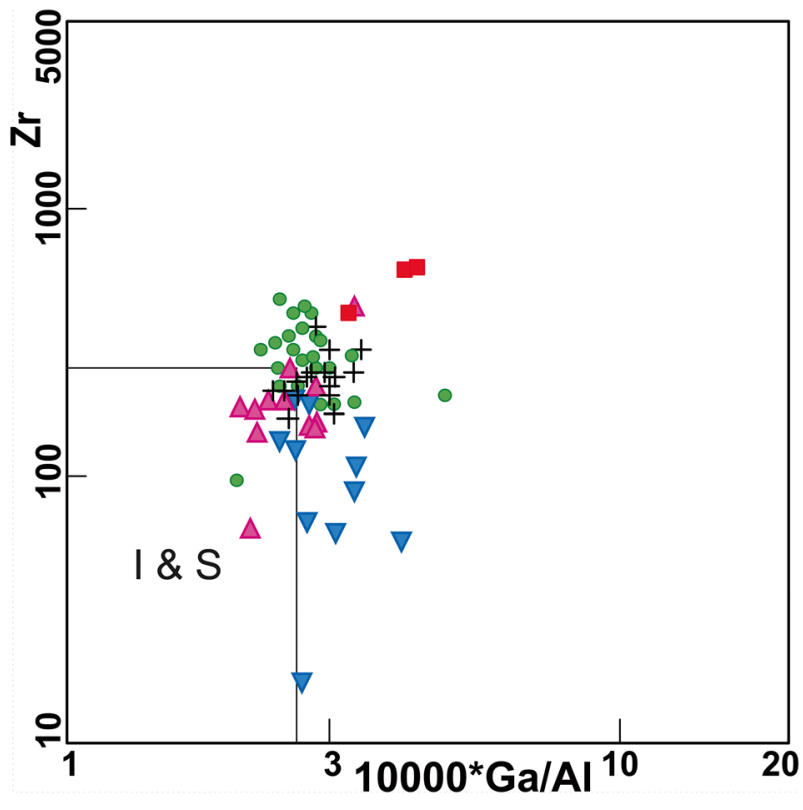

Fig. 6 Binary plot of $10,000 * \mathrm{Ga} / \mathrm{Al}$ vs. $\mathrm{Zr}$ (Whalen et al. 1987). Same symbols as in Fig. 2

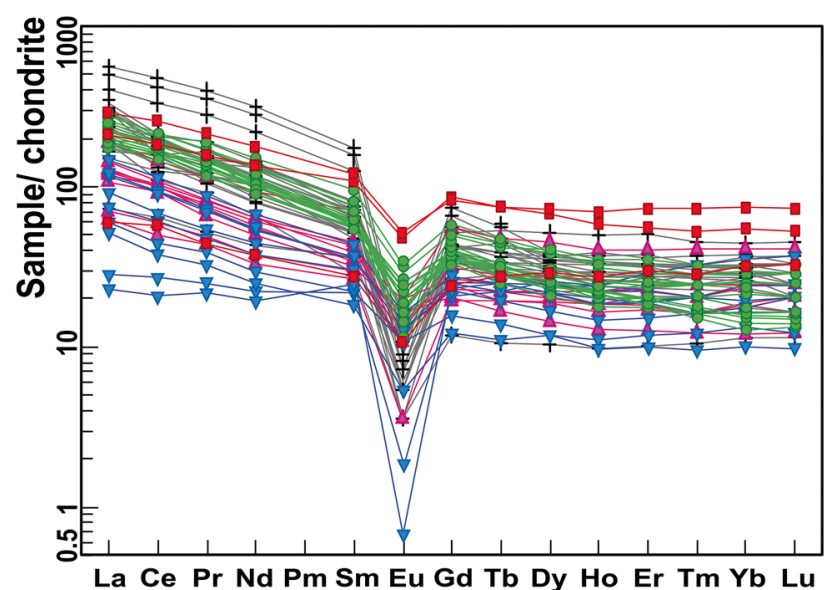

Fig. 7 Chondrite normalised REE patterns of the A-type rocks. Normalised values after Barrat et al. 2012. Same symbols as in Fig. 2

$\mathrm{SiO}_{2}, \mathrm{~K}_{2} \mathrm{O}, \mathrm{Fe}>\mathrm{Mg}, \mathrm{K}>\mathrm{Na}$ and low $\mathrm{TiO}_{2}, \mathrm{MgO}, \mathrm{CaO}$ and $\mathrm{P}_{2} \mathrm{O}_{5}$ bulk-rock content. The very low phosphorus content is comparable with other similar granites worldwide (cf. Whalen et al. 1987), and it is the typical geochemical feature of A-type granites, reflected in the low amount of fluorapatite in these $\mathrm{Ca}$, P-poor rocks. Low $\mathrm{P}$ content could be explained by the formation from melt-depleted lower crust after the main granite production during Variscan orogeny (Broska and Uher 2001). The R1-R2 classification diagram (de La Roche et al. 1980) indicates the transition of granite to alkali granite (Fig. 2). These are more alkali-calcic than alkalic (Fig. 3a) and more ferroan than magnesian (Fig. 3b) (according to Frost et al. 2001; Frost and Frost 2011). The relatively strong peraluminous character of some A-type rhyolites contrasts with the moderate peraluminous to metaluminous \pm peralkaline granites (Fig. 4). They also have relatively higher $\mathrm{Rb}, \mathrm{Nb}, \mathrm{Zr}$, Th, F, Ga/Al and occasional W, low Sr, Ba and V. However, two samples of Turčok granite show $\mathrm{Rb} / \mathrm{Sr}$ ratio close to zero (Fig. 5b), because of the Rb loss during albitization connected with a late metamorphic overprint of the rock (Uher et al. 2009; Kaur et al. 2012). All granite samples have high to moderate REE + Y content, seagull-shaped REE patterns with enriched LREE $\left(\mathrm{La}_{\mathrm{N}} / \mathrm{Sm}_{\mathrm{N}}>1\right)$, flat HREE $\left(\mathrm{Gd}_{\mathrm{N}} / \mathrm{Yb}_{\mathrm{N}} \sim 1\right)$ and pronounced negative Eu anomaly (Fig. 7) indicating the feldspar fractionation. The assessment of trace $\mathrm{Ga}$ content compared to various major and trace element parameters provides strong indication of the A-type characteristics (Fig. 6). This is typical of the anorogenic origin of the investigated granites and rhyolites. The studied A-type granites are part of the $\mathrm{A}_{2}$ group (Fig. 5), which is mainly derived from the continental crust (Eby 1992). This is confirmed by their low $\mathrm{Nb} / \mathrm{Ta}$ ratio (av. $\sim 12.2$ ) consistent with the average composition of the continental crust ( 11.4 , Rudnick and Gao 2003). The empirical classification proposed by Bonin et al. (2020) places them in the KCG group (K-rich calc-alkaline granitoids) as the closest match. The major and trace element bulk rock composition of the granites was plotted with Permian rhyolites of the Silicic Unit because these have similar geochemistry and zircon ages, thus indicating a common geotectonic setting (Uher et al. 2002b; Ondrejka et al. 2018b). Nevertheless, some geochemical signatures, e.g. scattered $\mathrm{A} / \mathrm{CNK}$ values: exceptionally high $\mathrm{K}$ in contrast to very low $\mathrm{Ca}$ and $\mathrm{Na}$ contents, indicate an obvious contribution of the hydrothermal processes to their geochemical evolution (Uher et al. 2002b);

(ii) Biotite chemistry (annite $>$ siderophyllite) with high Fe/ $\mathrm{Mg}$ ratio, significant $\mathrm{F}$ and $\mathrm{Cl}$ contents (max. $0.7 \mathrm{wt} \%$ $\mathrm{F}$ and $0.5 \mathrm{wt} \% \mathrm{Cl}$ ) and relatively low $\mathrm{Al}$ content (Uher and Broska 1996);

(iii) Primary magmatic zircon with a high $\mathrm{Zr} / \mathrm{Hf}$ ratio (generally over 50) and zircon typology with high I.A. parameter 700 (Uher and Marschalko 1993; Uher and Broska 1994, 1996). Both these features indicate a high-alkaline crystallisation environment typical for alkaline (Pupin 1980, 1992) and A-type granites (Breiter et al. 2014);

(iv) relatively high $\mathrm{Zr}$-saturation temperature (according to Boehnke et al. 2013): $780-920{ }^{\circ} \mathrm{C}$ for hypersolvus and $700-770{ }^{\circ} \mathrm{C}$ for subsolvus granites. These indicate crystallization from high- to mild-temperature 
Fig. 8 CL images of zircons from the A-type granites from West Carpathian-Pannonian region with illustrated analytical spots and corresponding ${ }^{206} \mathrm{~Pb} /{ }^{238} \mathrm{U}$ age values
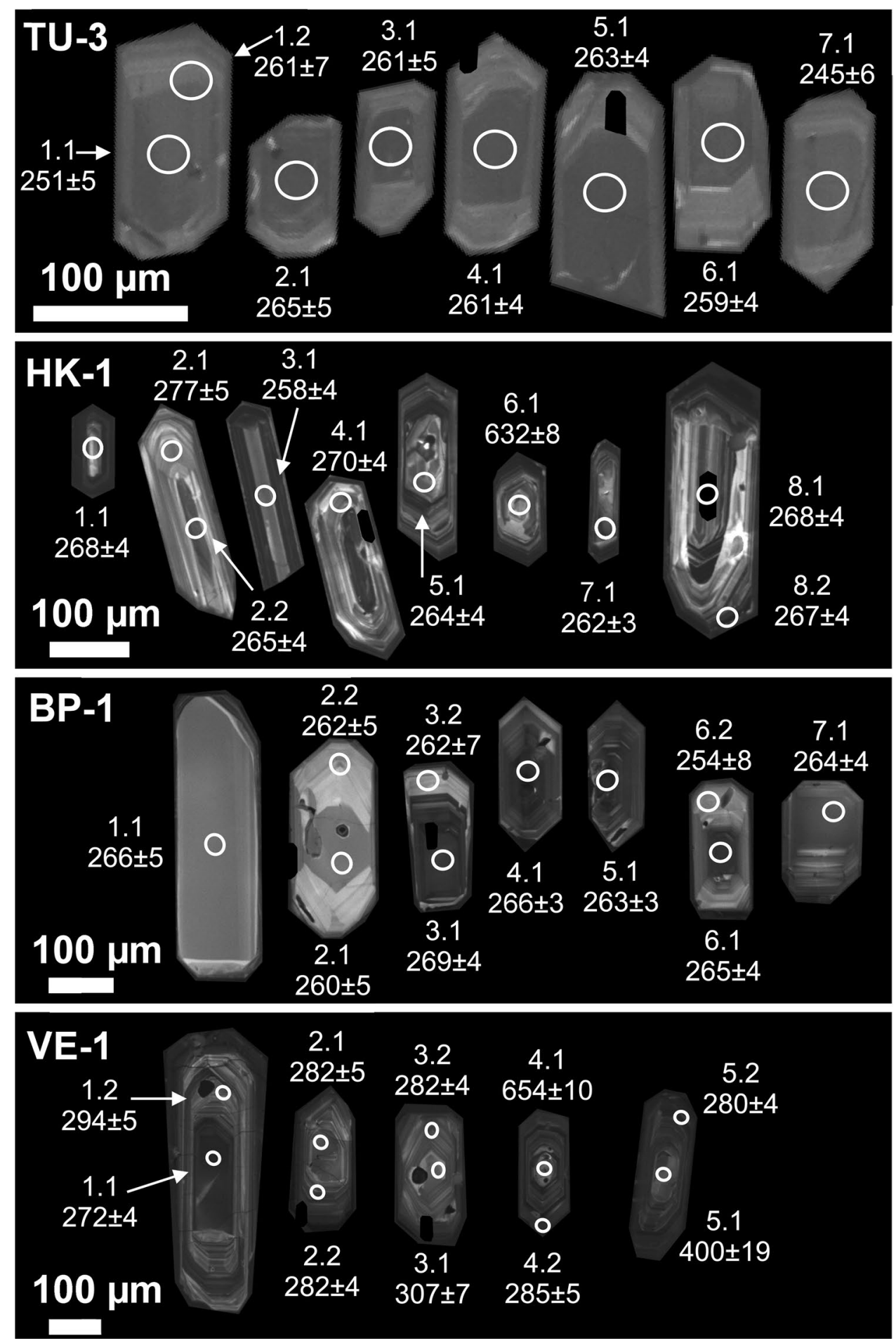

and dry magma. However, leucocrate differentiates of the Hrončok subsolvus granite reveal low Zr-saturation temperatures $\left(565-735^{\circ} \mathrm{C}\right)$. A rough correlation between the saturation temperature and the $\mathrm{Eu}$ anomaly and $\mathrm{SiO}_{2}$ is observed. Consistently, the temperature decreases as the Eu anomaly becomes more pronounced and the $\mathrm{SiO}_{2}$ content increases, giving confidence to the values obtained using the $\mathrm{Zr}$ thermometer;

(v) Presence of specific REE, Th and REE-Nb-Ta accessory minerals, such as allanite-(Ce), thorianite, gadolinite-hingganite-(Y), fergusonite-(Y) and aeschynite/ polycrase-(Y), which are characteristic for alkaline-rich 


\begin{tabular}{|c|c|c|c|}
\hline$\overline{0}: \overline{0}$ & 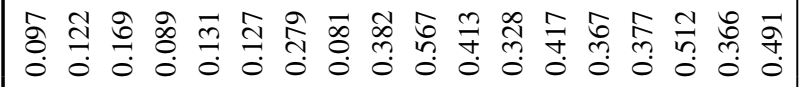 & 형 & 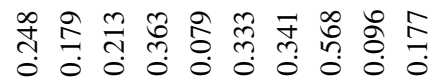 \\
\hline & & & \\
\hline$+i$ & 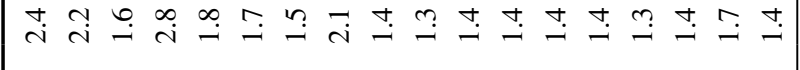 & +1 & $\stackrel{\infty}{\rightarrow} \stackrel{+}{\rightarrow} \stackrel{\infty}{\rightarrow} \stackrel{n}{\rightarrow} \stackrel{n}{\rightarrow} \underset{m}{-}$ \\
\hline 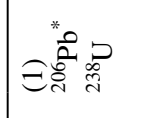 & 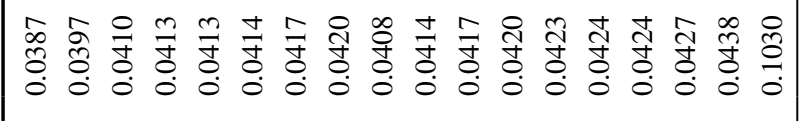 & 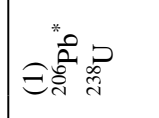 & 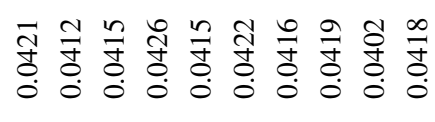 \\
\hline +i & 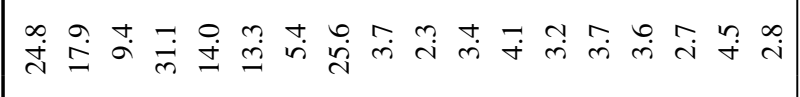 & in & 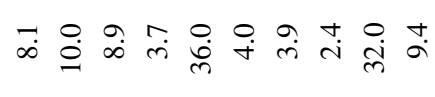 \\
\hline 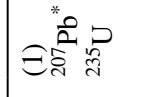 & 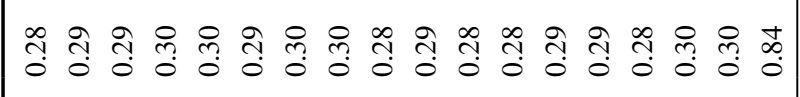 & 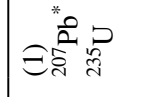 & 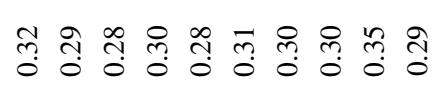 \\
\hline & 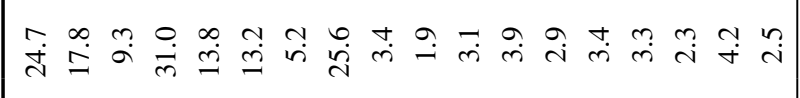 & 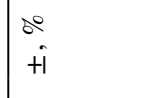 & 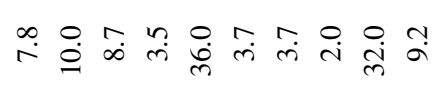 \\
\hline C: & 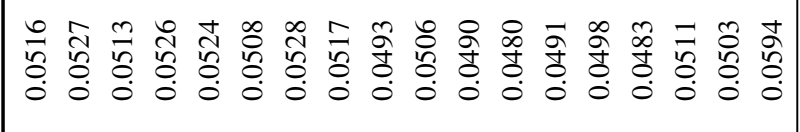 & అ离 & 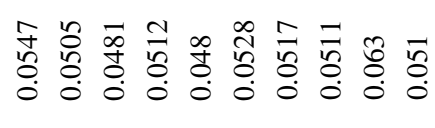 \\
\hline & 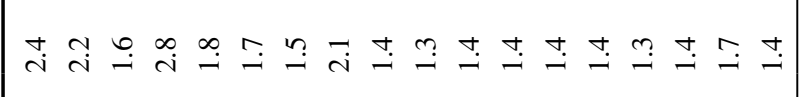 & $\begin{array}{l}\infty \\
+i\end{array}$ & 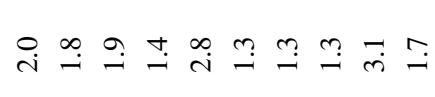 \\
\hline 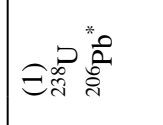 & 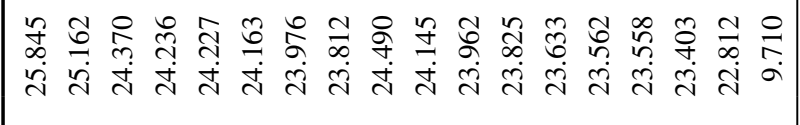 & 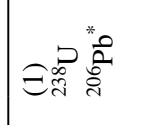 & 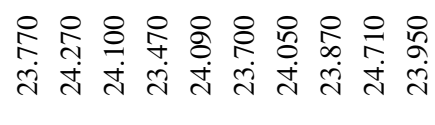 \\
\hline sి & 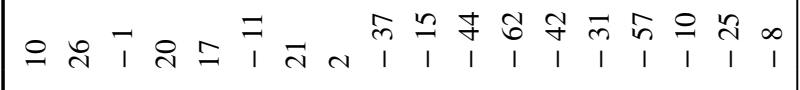 & \& & 兵 $\begin{array}{l}8 \\
1\end{array}$ i \\
\hline$\stackrel{0}{-}$ & 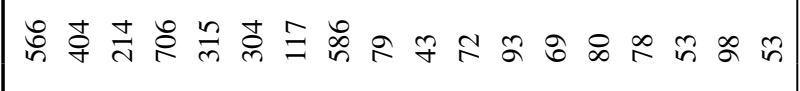 & $\stackrel{0}{-}$ & 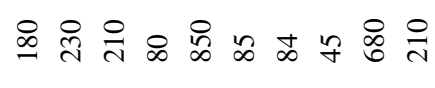 \\
\hline 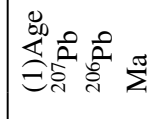 & 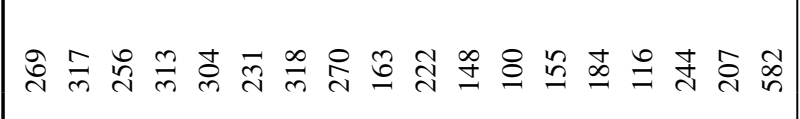 & 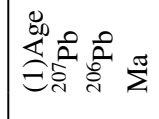 & 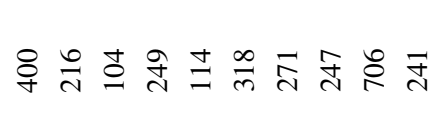 \\
\hline+1 & 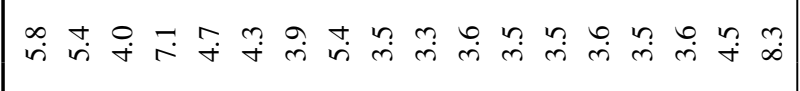 & +1 & 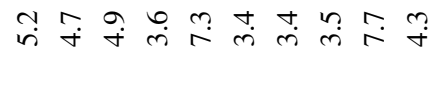 \\
\hline 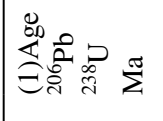 & 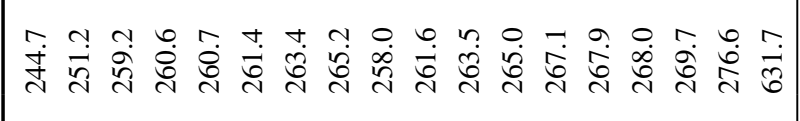 & 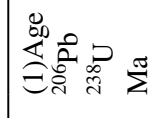 & 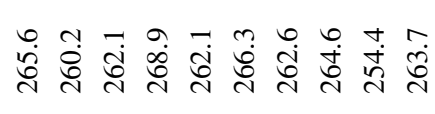 \\
\hline हैं & 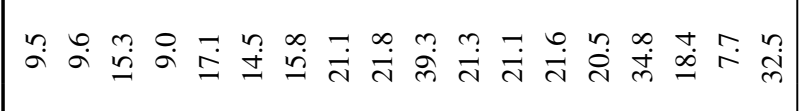 & 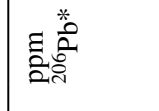 & 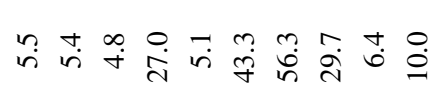 \\
\hline స్ & 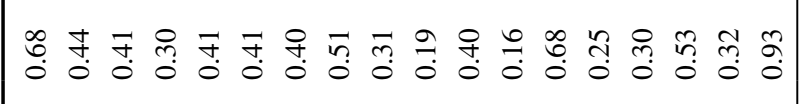 & 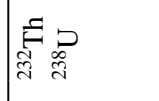 & 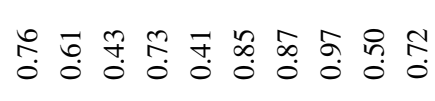 \\
\hline$\sum_{j}^{p}$ & :0 f & 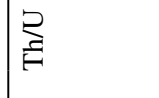 & 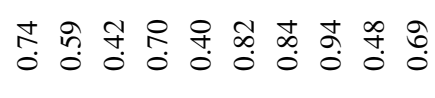 \\
\hline 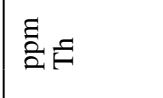 & 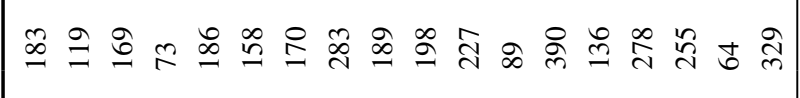 & 芯‡ & 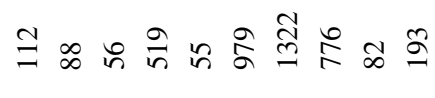 \\
\hline 苔っ & 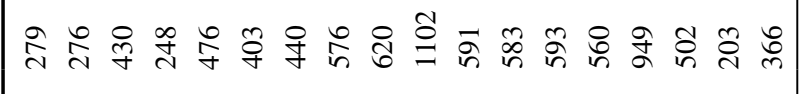 & 言っ & 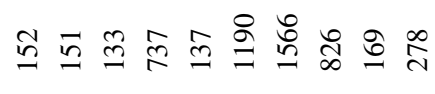 \\
\hline 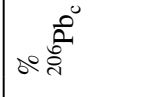 & 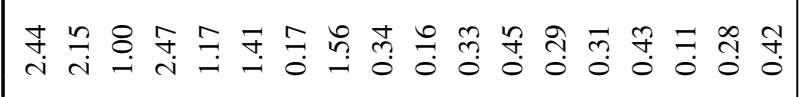 & 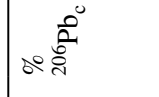 & 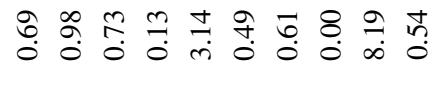 \\
\hline $\begin{array}{l}\text { oे } \\
\text { के }\end{array}$ & 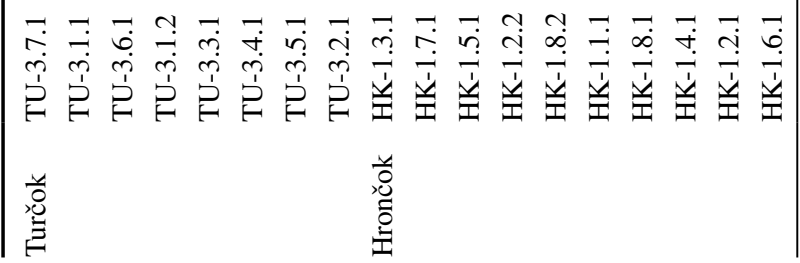 & & 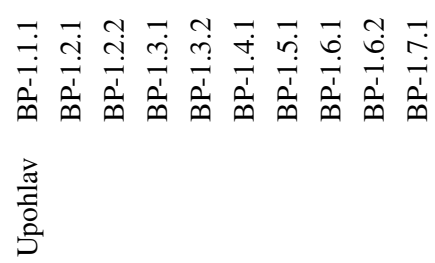 \\
\hline
\end{tabular}




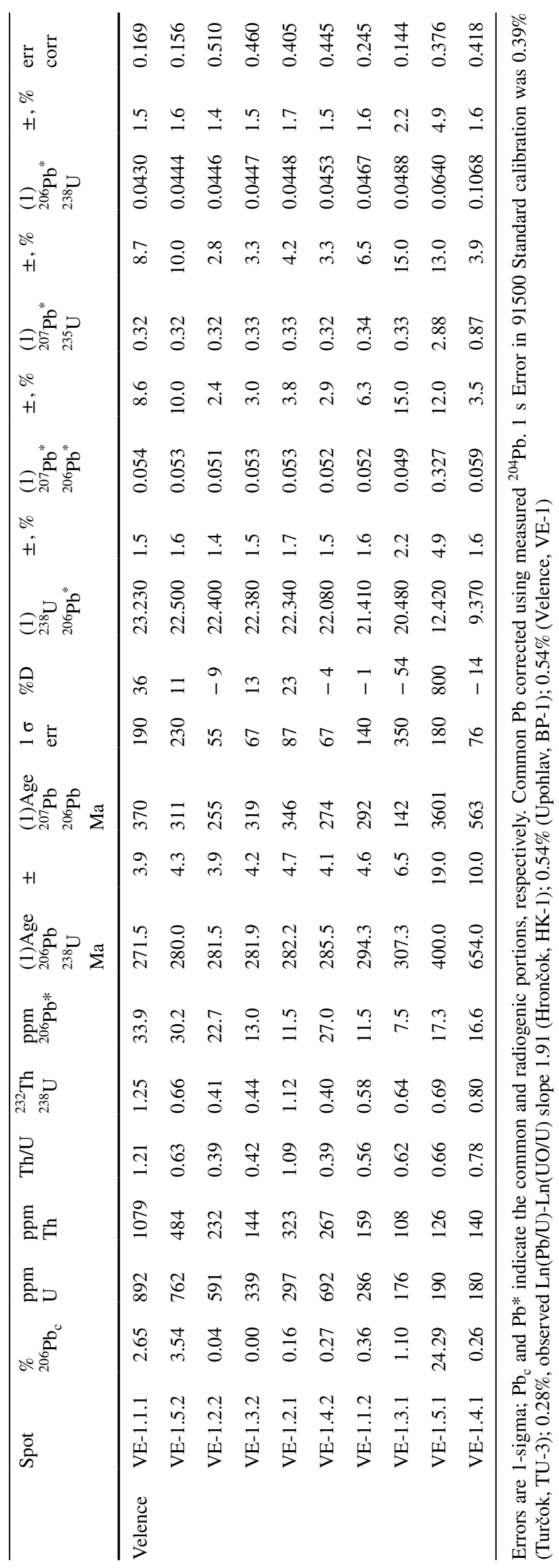




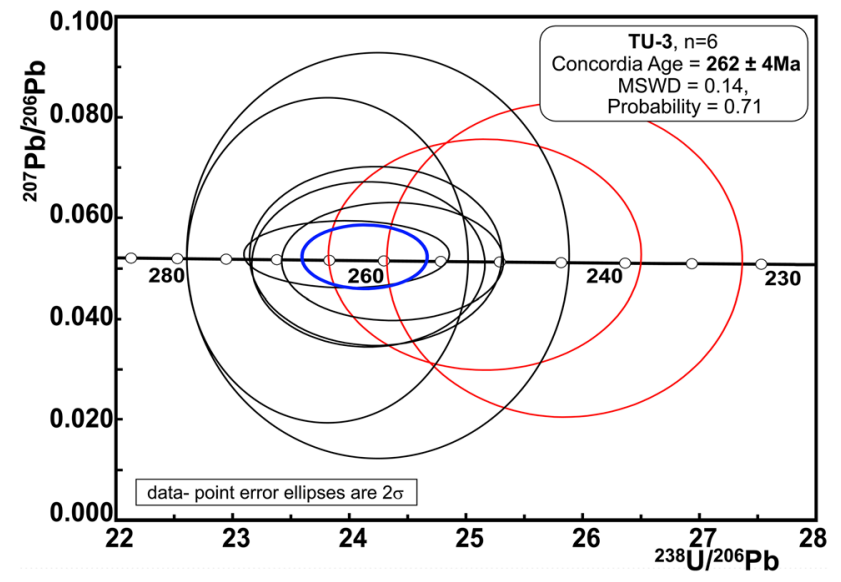

Fig. 9 Tera-Wasserburg Concordia diagram of SHRIMP zircon U$\mathrm{Pb}$ age plots for sample TU-3 (Turčok),

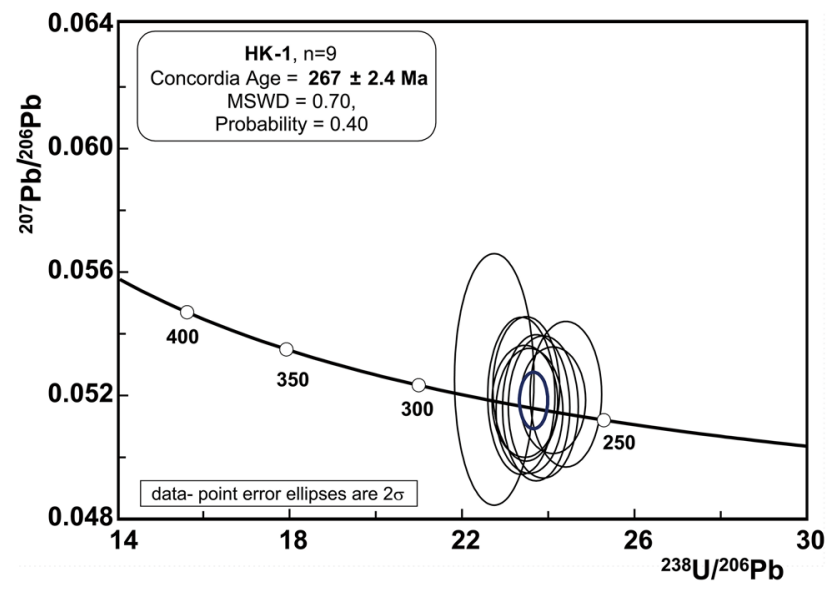

Fig. 10 Tera-Wasserburg Concordia diagram of SHRIMP zircon U$\mathrm{Pb}$ age plots for sample HK-1 (Hrončok)

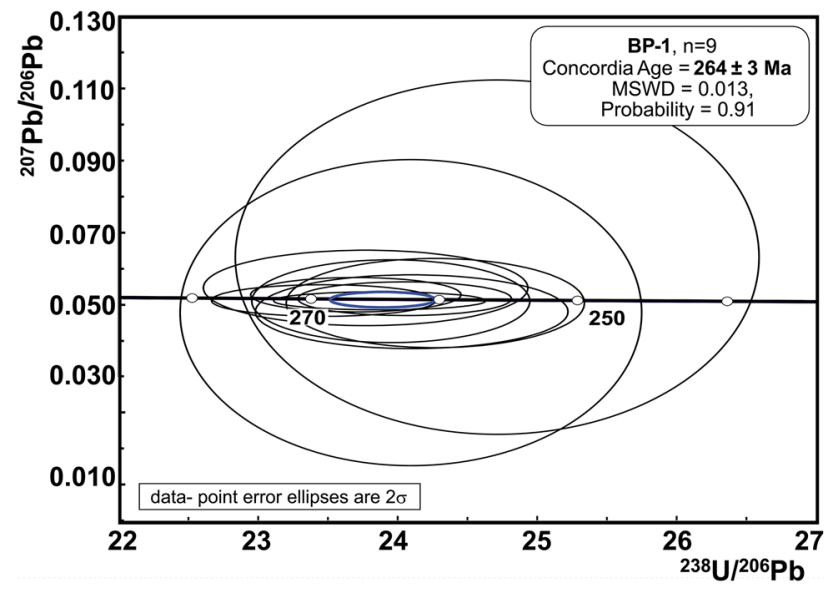

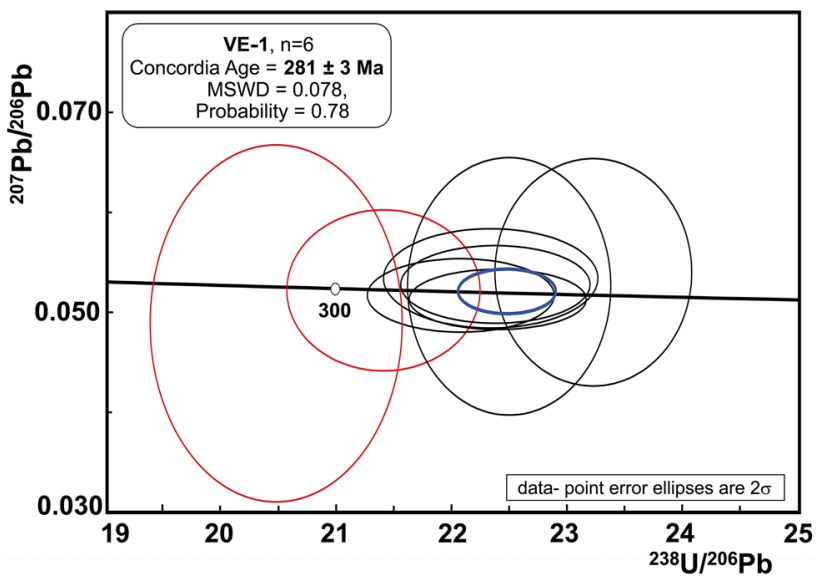

Fig. 12 Tera-Wasserburg Concordia diagram of SHRIMP zircon U$\mathrm{Pb}$ age plots for sample VE-1 (Velence)

Table 5 Oxygen isotope data of pure zircon concentrate (1-2 mg) from A-type granites

\begin{tabular}{llll}
\hline Granite body & Sample & $\delta^{18} \mathrm{O}$ Zrn $(\% o)$ & Average \\
\hline Turčok & TU-1 & 8.3 & - \\
Hrončok & ZK-26 & 8.1 & - \\
Upohlav & BP-1 & 7.5 & 8.1 \\
& BP-6.2 & 8.5 & \\
& BP-35 & 8.5 & \\
& BP-38 & 7.8 & 8.3 \\
Velence & VE-1 & 8.5 & \\
& VE-2 & 8.0 & \\
& VE-3 & 8.5 & \\
\hline
\end{tabular}

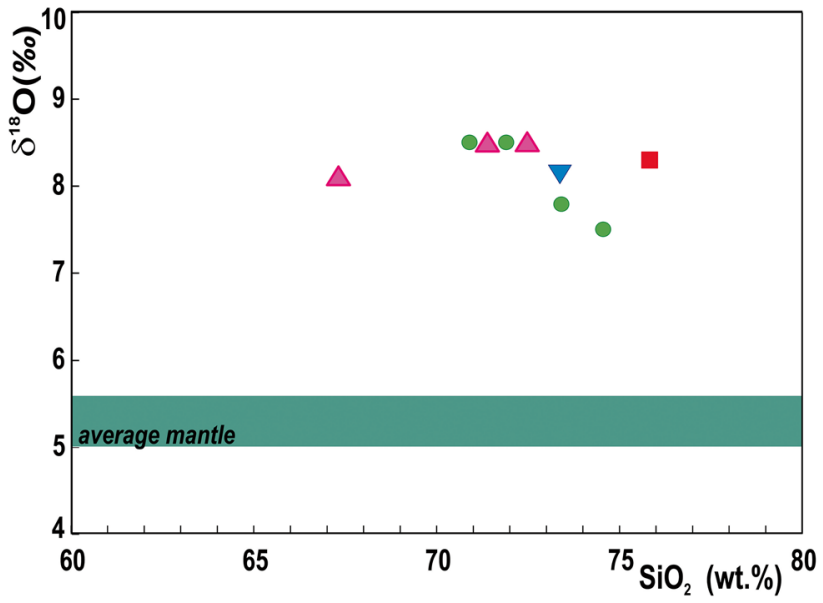

Fig. 13 Binary plot $\mathrm{SiO}_{2}$ vs. $\delta^{18} \mathrm{O}$ in zircon. Average mantle $5.3 \pm 0.3$ $\% o$ (Valley et al. 1998). Same symbols as in Fig. 2

Fig. 11 Tera-Wasserburg Concordia diagram of SHRIMP zircon U$\mathrm{Pb}$ age plots for sample BP-1 (Upohlav) 
magmatic suites (especially in the Turčok granite; Uher et al. 2009).

All (i-iv) geochemical and mineralogical features highlight the specific A-type characteristics of the studied granites (Uher and Broska 1996; Broska and Uher 2001; this study), which are typical in hot and dry post-orogenic to anorogenic granitic suites (cf. Whalen et al. 1987; Eby 1990; Frost and Frost 1997; Frost et al. 2001).

\section{Isotopic composition}

The isotopic compositions with whole rocks (WR) low to moderate ${ }^{87} \mathrm{Sr} /{ }^{86} \mathrm{Sr}_{(\mathrm{i})}=0.705-0.709$ and moderate $\varepsilon \mathrm{Nd}_{(\mathrm{i})}=-3.1$ to +1.9 indicate a variegated lower crustal meta-igneous protolith (Kohút et al. 1999; Kohút and Nabelek 2008; Table 1 in Magna et al. 2010). Positive zircon $\varepsilon \mathrm{Hf}_{(\mathrm{i})}=+0.2$ to +9.9 values are suggesting again a lower crustal meta-igneous protolith influenced by fluids from the metasomatized mantle (Kohút 2014, and Kohút unpublished data). However, lithium and sulphur whole-rock isotope signatures are not unambiguous. Mostly heavy Li isotope signatures with $\delta^{7} \mathrm{Li}=+5.05$ to $+6.67 \%$ of the Hrončok granite and whole-rock $\delta^{34} \mathrm{~S}=-0.69 \%$ of the Turčok granite probably reflect the derivation of these rocks from a mantle wedge modified by slab-derived fluids, whereas the modest value $\delta^{7} \mathrm{Li}=+1.5$ (Turčok) indicates rather a crustal source here (Kohút and Recio 2002; Magna et al. 2010). The isotope $\mathrm{U}-\mathrm{Sr}-\mathrm{Nd}-\mathrm{Hf}-\mathrm{O}$ signatures suggest the similar production from different crustal sources with varying contribution of mantle-derived basic materials to the post-collisional high-K calc-alkaline granitoid generation related to Arabian-Nubian Shield (Litvinovsky et al. 2021).

Zircon oxygen isotopic compositions show a low variation with a mean $\delta^{18} \mathrm{O}$ value of $8.3 \pm 0.36 \%$. The values are markedly higher $(2.5-3 \%$ o) than those of zircon from a primitive mantle-derived mafic magma (Valley 2003). For example, mantle zircon from the ultramafic rocks of Kimberley show a mean value of $5.3 \pm 0.3 \%$ (Valley et al. 1998). For zircon, the range of measured isotopic compositions indicates the melting of igneous rocks characteristic, for example, for the lower crust (Taylor and Sheppard, 1986). The whole-rock $\delta^{18} \mathrm{O}$ values from Western Carpathian A-type granites 7.8-8\% (Table 1 in Magna et al. 2010) are in good agreement with our zircon isotopic composition. The $\Delta(\mathrm{Gt}-\mathrm{Zc})$ (representing the difference $\delta^{18} \mathrm{O}_{\text {granite }}-\delta^{18} \mathrm{O}_{\text {zircon }}$ ) is close to $0 \%$, suggesting low or no crustal contamination of parental melt during crystallisation (Valley, 2003). In the present case, a biplot of $\mathrm{wt} \% \mathrm{SiO}_{2}$ of granite versus $\delta^{18} \mathrm{O}$ zircon shows a low variation for the $\mathrm{SiO}_{2}$ and $\delta^{18} \mathrm{O}$ values (Fig. 13). The $\delta^{18} \mathrm{O}$ values in zircon may be explained by the melting of igneous material of crustal origin and/or mantle basalts which interacted with low-temperature fluids
(Gregory and Taylor, 1981). Both $\mathrm{wt} \% \mathrm{SiO}_{2}$ and $\delta^{18} \mathrm{O}$ values are higher than, for example, those defined for the Neogene volcanic magmatism in the ALCAPA area (Seghedi et al. 2007), suggesting crustal and/or hydrothermal altered oceanic slab character of the melted material.

\section{Age of emplacement, Permian magmatic activity and origin}

The Permian magmatic crystallisation age interval of 280-260 Ma presented herein is the first reported insitu isotopic age of A-type granitic rocks in the Western Carpathians and Pannonian region determined by $\mathrm{U}-\mathrm{Pb}$ SHRIMP zircon dating. Previously obtained conventional multigrain $\mathrm{U}-\mathrm{Pb}$ zircon geochronological results (Cambel et al. 1977; Uher and Pushkarev 1994; Putiš et al. 2000) indicated a very broad interval of Permian to Triassic ages ( 285 to $240 \mathrm{Ma}$ ) for the Hrončok and Upohlav granites (Table 6). The measurements of Hrončok gave discordant age with lower intercept of $238.6 \pm 1.4 \mathrm{Ma}$ and upper intercept of $1096 \pm 44 \mathrm{Ma}$ (Putiš et al. 2000). However, several examples show that the $\mathrm{U}-\mathrm{Pb}$ zircon age calculated for the lower Discordia intersection for the multi-grain measurements of zircons is usually younger than the single-grain age of the same concordant zircons (Steiger et al 1993; Salnikova et al 1998). We attribute this rejuvenation to discrete $\mathrm{Pb}$ loss or $\mathrm{U}$ addition, particularly in cracked and partly damaged non-abraded zircon fraction. On the other hand, Triassic magmatic event $(245 \pm 3.3 \mathrm{Ma}$; U-Pb SIMS $)$, most likely connected with the pre-oceanic advanced early Middle Triassic continental rifting, has been registered in zircon from calc-alkaline basalt intercalations in the Dobšiná accretionary wedge mélange (Meliatic Unit) in the southern part of the Inner Western Carpathians (Putiš et al. 2019b). Moreover, Lower Triassic ages of granite magmatism in Bulgaria (Peytcheva et al. 2005; Bonev et al. 2019) suggests the continuous Permian- Triassic magmatic activity.

The age of the Velence granite massif $(\sim 280 \mathrm{Ma})$ is apparently older than the West-Carpathian occurrences (Turčok, Hrončok and Upohlav: 260-270 Ma). Their early Permian zircon U-Pb SHRIMP age concurs with the previously published $\mathrm{Rb}-\mathrm{Sr}$ whole-rock dating of $280 \mathrm{Ma}$ (Buda 1985; Buda et al. 2004) and the $\mathrm{K}-\mathrm{Ar}$ and $\mathrm{Rb}-\mathrm{Sr}$ biotite dating of 270-290 Ma (Gyalog and Horváth 2004). The monazite in-situ EPMA dating $(289 \pm 3 \mathrm{Ma})$ also supports the Permian (Cisuralian) age, while xenotime EPMA age $(266 \pm 5 \mathrm{Ma})$ registers post-magmatic (subsolidus) recrystallization and is clearly comparable to SHRIMP zircon ages for the Western Carpathian A-type granite occurrences. This further suggests that fluid-assisted xenotime-(Y) recrystallization is connected with increased heat transfer during the granites' emplacement (Sobocký et al. 2020). Moreover, two distinct Permian dacitic to rhyolitic volcanic activities were 
Table 6 Summary of all published igneous ages of A-type granites and rhyolites in the Western Carpathians and Transdanubian Central Range and selected accompanied magmatic rocks in the area

\begin{tabular}{|c|c|c|c|}
\hline Dated rocks & Age (Ma) & Method & References \\
\hline $\begin{array}{l}\text { Turčok A-type granite } \\
\text { (Gemeric Unit, Slovakia) }\end{array}$ & $262 \pm 4$ & $\mathrm{U}-\mathrm{Pb}$ (in-situ zircon) & This work \\
\hline \multirow{6}{*}{$\begin{array}{l}\text { Hrončok A-type granite } \\
\text { (Veporic Unit, Slovakia) }\end{array}$} & 260 & $\mathrm{U}-\mathrm{Pb}$ (multi-zircon) & Cambel et al. (1977) \\
\hline & $285 \pm 5-253 \pm 2$ & $\mathrm{Rb}-\mathrm{Sr}$ (whole-rock) & Cambel et al. (1989) \\
\hline & $278 \pm 11$ & $\mathrm{U}-\mathrm{Pb}$ (multi-zircon) & Kotov et al. (1996) \\
\hline & $239 \pm 1$ & $\mathrm{U}-\mathrm{Pb}$ (multi-zircon) & Putiš et al. (2000) \\
\hline & $263 \pm 19$ & chemical Th-U-Pb (monazite) & Finger et al. (2003) \\
\hline & $267 \pm 2$ & $\mathrm{U}-\mathrm{Pb}$ (in-situ zircon) & This work \\
\hline \multirow{2}{*}{$\begin{array}{l}\text { Upohlav A-type granite } \\
\text { (Oravic Unit, Slovakia) }\end{array}$} & $274 \pm 13$ & $\mathrm{U}-\mathrm{Pb}$ (multi-zircon) & Uher and Pushkarev (1994) \\
\hline & $264 \pm 3$ & $\mathrm{U}-\mathrm{Pb}$ (in-situ zircon) & This work \\
\hline \multirow{5}{*}{$\begin{array}{l}\text { Velence A-type granite } \\
\text { (Transdanubic Unit, Hungary) }\end{array}$} & $280 \pm 7$ & $\mathrm{Rb}-\mathrm{Sr}$ (biotite) & Buda (1985) \\
\hline & $291-271$ & $\mathrm{~K}-\mathrm{Ar} ; \mathrm{Rb}-\mathrm{Sr}$ (biotite) & Gyalog and Horváth (2004) \\
\hline & $289 \pm 3$ & chemical Th-U-Pb (monazite) & Sobocký et al. (2020) \\
\hline & $266 \pm 5$ & chemical Th-U-Pb (xenotime) & Sobocký et al. (2020) \\
\hline & $281 \pm 3$ & $\mathrm{U}-\mathrm{Pb}$ (in-situ zircon) & This work \\
\hline \multirow{2}{*}{$\begin{array}{l}\text { A-type rhyolites } \\
\text { (Silicic Unit, Slovakia) }\end{array}$} & $263 \pm 4$ & chemical Th-U-Pb (monazite) & Demko and Hraško (2013) \\
\hline & $269-263 \pm 2$ & U-Pb (in-situ zircon) & Ondrejka et al. (2018b) \\
\hline \multirow{3}{*}{$\begin{array}{l}\text { volcanic dykes (Tatric/Infratatric Units, } \\
\text { Slovakia) }\end{array}$} & $267-262 \pm 2$ & $\mathrm{U}-\mathrm{Pb}$ (in-situ zircon) & Putiš et al. (2016) \\
\hline & $260 \pm 1$ & $\mathrm{U}-\mathrm{Pb}$ (in-situ zircon) & Pelech et al. (2017) \\
\hline & $259 \pm 3$ & chemical Th-U-Pb (monazite) & Pelech et al. (2017) \\
\hline \multirow{2}{*}{$\begin{array}{l}\text { lamprophyre dykes } \\
\text { (Tatric Unit, Slovakia) }\end{array}$} & $263 \pm 3$ & $\mathrm{U}-\mathrm{Pb}$ (in-situ apatite) & Spišiak et al. (2018) \\
\hline & $259 \pm 3$ & $\mathrm{U}-\mathrm{Pb}$ (in-situ apatite) & Spišiak et al. (2019) \\
\hline $\begin{array}{l}\text { metaandesites/ metabasalts } \\
\text { (Veporic Unit, Slovakia) }\end{array}$ & $263 \pm 3$ & U-Pb (in-situ zircon) & Vozárová et al. (2020) \\
\hline \multirow{10}{*}{$\begin{array}{l}\text { Spiš-Gemer rare-metal } \\
\text { S-type granites } \\
\text { (Gemeric Unit, Slovakia) }\end{array}$} & $290 \pm 40-223 \pm 32$ & $\mathrm{Rb}-\mathrm{Sr}$ (whole-rock) & Kovách et al. (1986) \\
\hline & $282 \pm 2$ & $\mathrm{Rb}-\mathrm{Sr}$ (whole-rock) & Cambel et al. (1989) \\
\hline & $276 \pm 13-272 \pm 11$ & chemical Th-U-Pb (monazite) & Finger and Broska (1999) \\
\hline & $265 \pm 20$ & $\mathrm{U}-\mathrm{Pb}$ (single-zircon) & Poller et al. (2000) \\
\hline & $303-241$ & $\mathrm{U}-\mathrm{Pb}$ (single-zircon) & Poller et al. (2002) \\
\hline & $276 \pm 13-263 \pm 28$ & chemical Th-U-Pb (monazite) & Finger et al. (2003) \\
\hline & $264 \pm 1-262 \pm 1$ & Re-Os (molybdenite) & Kohút and Stein (2005) \\
\hline & $277 \pm 2-257 \pm 4$ & $\mathrm{U}-\mathrm{Pb}$ (in-situ zircon) & Radvanec et al. (2009) \\
\hline & $275-250$ & chemical Th-U-Pb (monazite) & Radvanec et al. (2009) \\
\hline & $\begin{array}{l}258 \pm 19 \\
274 \pm 2-262 \pm 0.1\end{array}$ & $\begin{array}{l}\mathrm{U}-\mathrm{Pb} \text { (in-situ zircon) } \\
\mathrm{U}-\mathrm{Pb} \text { (in-situ zircon) }\end{array}$ & $\begin{array}{l}\text { Kubiš and Broska (2010) } \\
\text { Villaseñor et al. (2021) }\end{array}$ \\
\hline \multirow{3}{*}{$\begin{array}{l}\text { rhyolitic to andesitic volcanics } \\
\text { (Gemeric Unit, Slovakia) }\end{array}$} & $275 \pm 3-273 \pm 3$ & $\mathrm{U}-\mathrm{Pb}$ (in-situ zircon) & Vozárová et al. (2009) \\
\hline & $275 \pm 4-266 \pm 2$ & $\mathrm{U}-\mathrm{Pb}$ (in-situ zircon) & Vozárová et al. (2012) \\
\hline & $257 \pm 3-256 \pm 4$ & Re-Os (molybdenite) & Kohút et al. (2013) \\
\hline $\begin{array}{l}\text { Grobgneis S-type granite } \\
\text { (L. Austroalpine Unit, Austria) }\end{array}$ & $272 \pm 1-268 \pm 3$ & $\mathrm{U}-\mathrm{Pb}$ (in-situ zircon) & Yuan et al. (2020) \\
\hline $\begin{array}{l}\text { acidic volcanics } \\
\text { (Transdanubic Unit, Hungary) }\end{array}$ & $291 \pm 5$ & $\mathrm{U}-\mathrm{Pb}$ (single-zircon) & Lelkes-Felvári and Klötzli (2004) \\
\hline $\begin{array}{l}\text { dacitic volcanics } \\
\text { (Transdanubic Unit, Hungary) }\end{array}$ & $\sim 281$ & $\mathrm{U}-\mathrm{Pb}$ (in-situ zircon) & Szemerédi et al. (2020a) \\
\hline $\begin{array}{l}\text { rhyodacitic volcanics } \\
\text { (Tisza Mega-Unit, Hungary) }\end{array}$ & $\sim 267-260$ & $\mathrm{U}-\mathrm{Pb}$ (in-situ zircon) & Szemerédi et al. (2020a) \\
\hline
\end{tabular}

recognized by $\mathrm{U}-\mathrm{Pb}$ zircon geochronology from the adjacent tectonic units: an older stage ( 290-280 Ma, Cisuralian) from the Southern Carpathians (Kędzior et al. 2020) and a younger stage of volcanic activity ( 270-260 Ma, Guadalupian) in the Tisza Mega-Unit (Lelkes-Felvári and Klötzli 2004; Szemerédi et al. 2020a, b). 
Permian evolution in the Western Carpathians is similar from a regional distribution viewpoint, as follows; the beginning of Permian volcanic activity was documented by detrital early Cisuralian magmatic zircons (300-290 Ma) in the sediments of the Hronic, and Turnaic units (Vozárová et al. 2018, 2019). The main Permian volcanic activity is represented by Cisuralian to Guadalupian ( 290-260 Ma) acidic subvolcanic porphyries, rhyolites, trachyrhyolites and rhyodacites with A-type affinity and calc-alkaline basaltic metaandesites/metabasalts with riftogeneous within-plate characteristics in Tatric, Veporic, Gemeric and Meliatic units (Broska et al. 1993; Korikovsky et al. 1995; Kotov et al. 1996; Vozárová et al. 2009, 2012, 2016, 2020; Kohút et al. 2013; Putiš et al. 2019a, b). These are accompanied in some places by Guadalupian volcanic dykes (270-260 Ma) which crosscut the crystalline basement in the Považský Inovec Mts., the Tatric/ Infratatric Unit (Putiš et al. 2016; Pelech et al. 2017) and Guadalupian A-type rhyolites (270-260 Ma) in the Muráñ Nappe, Silicic Unit (Demko and Hraško 2013; Ondrejka et al. 2018b). Moreover, intrusions of Guadalupian lamprophyre dykes ( $260 \mathrm{Ma}$ ) have been reported in the Tatric crystalline basement as a product of a metasomatised mantle wedge (Spišiak et al. 2018, 2019). All these mostly felsic magmatic rocks and the coeval raremetal ( $\mathrm{Sn}-\mathrm{Nb}-\mathrm{Ta}-\mathrm{W}-\mathrm{Li}$ ) S-type Spiš-Gemer granites in the Gemeric Unit ( 280-250 Ma) are considered to be formed by the Variscan post-orogenic activity or a post-orogenic collapse (Petrík et al. 1995; Uher and Broska 1996; Finger and Broska 1999; Poller et al. 2002; Kohút and Stein 2005; Radvanec et al. 2009; Radvanec and Grecula 2016; Villaseñor et al. 2021) that partly overlaps in time with the beginning of Alpine pre-orogenic continental rifting, Pangea breakup and the Neotethys Meliata-Hallstatt Basin opening (Putiš et al. 2000, 2019a, b) (Table 6).

There are also analogous, 280-250 Ma ages documenting widespread magmatic activity in the broader AlpineCarpathian area. Examples include the 265 Ma diorite to granite porphyry of the Highiş Igneous Complex, Apuseni Mountains (Romanian Carpathians) which represent a halogen-rich A-type granite suite (Pană et al. 2002; Bonin and Tatu 2016). Permian leucogranites and associated spodumene-bearing granitic pegmatites from the Austroalpine Unit, Eastern Alps (Austria) yield the U-Pb and $\mathrm{Sm}-\mathrm{Nd}$ ages of magmatic garnet in the interval of 245 to $280 \mathrm{Ma}$ (Knoll et al. 2018; Putiš et al. 2019a). The LA-ICP-MS $\mathrm{U}-\mathrm{Pb}$ dating of zircon from porphyric metagranites (Grobgneiss) of the Lower Austroalpine units (Austria) gave a narrow interval of $272.2 \pm 1.2$ to $267.6 \pm 2.9 \mathrm{Ma}$; they represent high-K calc-alkaline to shoshonitic suite with S-type affinity, associated with gabbroic bodies (Yuan et al. 2020). High-K calc-alkaline lamprophyres of the Argentera-Mercantour Massif, Western Alps (Filippi et al. 2020) and the post-orogenic extensional basaltic andesites to rhyolites and granites of Athesian Volcanic Group (Southern Alps, Italy) have single-zircon U-Pb ages between 290 and $275 \mathrm{Ma}$ (Marocchi et al. 2008; Morelli et al. 2012). In addition, Permian granites of the Aya pluton and lamprophyre dykes in the Pyrenees were emplaced at $270 \mathrm{Ma}$ (Denèle et al. 2012).

The rare presence of 650-630 Ma inherited zircon cores in some samples indicates the admixture of Neoproterozoic material in the investigated A-type granite protolith. This systematic presence of older material is also supported by the sporadic occurrence of 670-640-Ma-old monazite-(Ce) domains in the Velence granite dated by EPMA in-situ chemical dating method (Sobocký et al. 2020).

Petrogenetic models for A-type granites commonly invoke igneous source (e.g., Collins et al. 1982; Creaser et al. 1991; Frost and Frost 1997) and peraluminous granites exhibiting A-type characteristics have been documented elsewhere (e.g. Huang et al. 2011; Sun et al. 2011; Dahlquist et al. 2014; Morales Cámera et al. 2018; Gao et al. 2020). These granites are usually derived from an infracrustal felsic source (King et al. 1997) alternatively with a dominant metasedimentary component rich in feldspars (e.g. Huang et al. 2011; Dahlquist et al. 2014). The optimal melting conditions are low pressure and high temperature, which can be created by the extensional setting (Frost and Frost 2011; Gao et al. 2020). In our case, partial melting of an Early Variscan, or perhaps of the Pan-African lower crustal meta-igneous rocks, possibly with a small contribution of meta-basic mantle-derived material provides a likely origin for our investigated A-type granite intrusions. The possible involvement of a more basic lower crustal to upper mantle protolith is also suggested by an occurrence of rare mafic enclaves of biotite tonalite composition at Velence (Uher and Broska 1996). Moreover, these global tectono-magmatic events are generally considered to have been related to the opening of the Meliata-Hallstatt marginal sea of the Neotethys Ocean (e.g., Kozur 1991; Ziegler and Stampfli 2001; Vai 2003; Muttoni et al. 2009; Cassinis et al. 2012) and to Pangea disintegration (Isozaki 2009; Putiš et al. 2019a, b).

The change in geochemical trend from subduction-related calc-alkaline to post-orogenic/anorogenic intracontinental alkali-calcic/alkaline magmatic suites is clearly documented across Variscan Europe (Bonin 1990, 1993, 1998) and in other regions worldwide (e.g., Nikishin et al. 2002; Konopelko et al. 2007; Shellnutt and Zhou 2007). Here, Permian magmatism and metamorphism suggest asthenospheric upwelling triggering both mantle and continental crust melting in the extensionally thinned underplated lithosphere (e.g., Nikishin et al. 2002; Shellnutt and Zhou 2007; Sinigoi et al. 2011, 2016; Klötzli et al. 2014; Kunz et al. 2018; Putiš et al. 2018). 


\section{Conclusions}

The Western Carpathian A-type granite intrusions (Turčok, Hrončok and Upohlav) were emplaced at 270-260 Ma, and the Pannonian Velence A-type granite was emplaced earlier at $280 \mathrm{Ma}$. This time gap (10 to $20 \mathrm{Ma}$ ) between magmatic solidification of the Transdanubian Central Range (Velence) granite and other West-Carpathian A-type granite occurrences most likely reflects their different palaeo-tectonic position during NW-ward prograding of rifting in the Neotethyan continental margin.

The geochemical and mineralogical data clearly indicate mostly ferroan and peraluminous A-type affinity with high total-alkali and $\mathrm{FeO}_{\mathrm{Tot}} / \mathrm{MgO}, \mathrm{Ga} / \mathrm{Al}$ ratios. They are further classified as $\mathrm{A}_{2}$-type suite which is compositionally closer to average continental crust, and this is also supported by the relatively higher zircon $\delta^{18} \mathrm{O}$ isotope value $(+7.5$ to +8.5$)$.

The formation of these mostly peraluminous A-type granites is most likely related to the partial melting of the ancient lower crustal quartzo-feldspatic rocks with the possible small contribution of meta-basic material from the mantle. It was linked to the post-orogenic extensional tectonic regime within the Variscan orogenic belt and chronologically overlapping extension of the new (Alpine) Wilson cycle.

Supplementary Information The online version contains supplementary material available at https://doi.org/10.1007/s00531-021-02064-2.

Acknowledgements We thank Ilya Paderin for assistance with SHRIMP U-Pb zircon analysis and R.J. Marshall for language review. This work was supported by the Slovak Research and Development Agency (contract APVV-18-0065, APVV-18-0107, APVV-19-0065), and the VEGA Agency (Nos. 1/0151/19, 1/0467/20). Finally, we thank Bernard Bonin, one anonymous reviewer, and Wolf-Christian Dullo (Editor in Chief) for their constructive suggestions.

Open Access This article is licensed under a Creative Commons Attribution 4.0 International License, which permits use, sharing, adaptation, distribution and reproduction in any medium or format, as long as you give appropriate credit to the original author(s) and the source, provide a link to the Creative Commons licence, and indicate if changes were made. The images or other third party material in this article are included in the article's Creative Commons licence, unless indicated otherwise in a credit line to the material. If material is not included in the article's Creative Commons licence and your intended use is not permitted by statutory regulation or exceeds the permitted use, you will need to obtain permission directly from the copyright holder. To view a copy of this licence, visit http://creativecommons.org/licenses/by/4.0/.

\section{References}

Balen D, Schneider P, Massone H-J, Opitz J, Luptáková J, Putiš M, Petrinec Z (2020) The Late Cretaceous A-type alkali-feldspar granite from the Mt. Požeška (N. Croatia): potential marker of fast magma ascent in the Europe-Adria suture zone. Geol Carpath 71:361-381. https://doi.org/10.31577/GeolCarp.71.4.5
Barrat JA, Zanda B, Moynier F, Bollinger C, Liorzou C, Bayon G (2012) Geochemistry of CI chondrites: major and trace elements, and $\mathrm{Cu}$ and $\mathrm{Zn}$ Isotopes. Geochim Cosmochim Acta 83:79-92. https://doi.org/10.1016/j.gca.2011.12.011

Black LP, Kamo SL, Allen CM, Aleinikoff JN, Davis DW, Korsch RJ, Foudoulis C (2003) TEMORA 1: a new zircon standard for Phanerozoic U-Pb geochronology. Chem Geol 200:155-170. https:// doi.org/10.1016/S0009-2541(03)00165-7

Boehnke P, Watson EB, Trail D, Harrison TM, Schmitt AK (2013) Zircon saturation re-revisited. Chem Geol 351:324-334. https:// doi.org/10.1016/j.chemgeo.2013.05.028

Bonev N, Filipov P, Raicheva R, Moritz R (2019) Timing and tectonic significance of Paleozoic magmatism in the Sakar unit of the Sakar-Strandzha Zone, SE Bulgaria. Int Geol Rev 61:1957-1979. https://doi.org/10.1080/00206814.2019.1575090

Bonin B (1990) From orogenic to anorogenic settings: evolution of granitoid suites after a major orogenesis. Geol J 25:261-270. https://doi.org/10.1002/gj.3350250309

Bonin B (1993) Late Variscan magmatic evolution of the Alpine basement. In: von Raumer JF, Neubauer F (eds) Pre-Mesosoic geology in the Alps. Springer, Berlin, pp 171-201

Bonin B (1998) Orogenic to non-orogenic magmatic events: Overview of the late Variscan magmatic evolution of the Alpine belt. Tr J Earth Sci 7:133-143

Bonin B (2004) Do coeval mafic and felsic magmas in postcollisional to within-plate regimes necessarily imply two contrasting, mantle and crustal, sources? A review. Lithos 78:1-24. https://doi.org/ 10.1016/j.lithos.2004.04.042

Bonin B (2007) A-type granites and related rocks: Evolution of a concept, problems and prospects. Lithos 97:1-29. https://doi.org/10. 1016/j.lithos.2006.12.007

Bonin B (2008) Death of super-continents and birth of oceans heralded by discrete A-type granite igneous events: the case of the Variscan-Alpine Europe. J Geosci 53:237-252. https://doi.org/ 10.3190/jgeosci.036

Bonin B, Tatu M (2016) Cl-rich hydrous mafic mineral assemblages in the Highiş massif, Apuseni Mountains, Romania. Miner Pet 110:447-469. https://doi.org/10.1007/s00710-015-0419-x

Bonin B, Azzouni-Sekkal A, Bussy F, Ferrag S (1998) Alkali-calcic and alkaline post-orogenic (PO) granite magmatism: petrologic constraints and geodynamic settings. Lithos 45:45-70. https:// doi.org/10.1016/S0024-4937(98)00025-5

Bonin B, Janoušek V, Moyen J-F (2020) Chemical variation, modal composition and classification of granitoids. In: Janoušek V, Bonin B, Collins WJ, Farina F, Bowden A (eds) Post-Archean granitic rocks: contrasting petrogenetic processes and tectonic environments. Geological Society London Special Publications, Geol Soc London Spec Publ 491:9-51. https://doi.org/10.1144/ SP491-2019-138

Breiter K, Lamarão CN, Borges RMK, Agnol RD (2014) Chemical characteristics of zircon from A-type granites and comparison to zircon of S-type granites. Lithos. https://doi.org/10.1016/j. lithos.2014.02.004

Broska I, Uher P (2001) Whole-rock chemistry and genetic typology of the West-Carpathian Variscan granites. Geol Carpath 52:79-90

Broska I, Vozár J, Uher P, Jakabská K (1993) Zircon typology from the Permian rhyolite-dacites and their pyroclastics (Western Carpathians). In: Rakús M, Vozár J (eds) Geodynamical evolution and deep structure of the Western Carpathians. GÚDŠ Publisher, Bratislava, pp 151-158

Broska I, Williams CT, Uher P, Konečný P, Leichmann J (2004) The geochemistry of phosphorus in different granite suites of the Western Carpathians, Slovakia: the role of apatite and P-bearing feldspar. Chem Geol 205:1-15. https://doi.org/10.1016/j.chemg eo.2003.09.004 
Broska I, Petrík P, Uher P (2012) Paragenesis of typomorphic accessory minerals vs. typology of granitic rocks: examples from Western Carpathians, Slovakia. Acta Min Petrogr Abstr Ser Szeged 7:22

Buda G (1985) Origin of collision-type Variscan granitoids in Hungary, West-Carpathian and Central Bohemian Pluton. Unpubl. PhD. Thesis, Budapest, 1-148 (in Hungarian)

Buda G, Nagy G (1995) Some REE-bearing accessory minerals in two types of Variscan granitoids, Hungary. Geol Carpath 46:67-78

Buda G, Koller F, Ulrych J (2004) Petrochemistry of Variscan granitoids of Central Europe: Correlation of Variscan granitoids of the Tisia and Pelsonia Terranes with granitoids of the Moldanubicum, Western Carpathian and Southern Alps. A review: part I. Acta Geol Hung 47:117-138. https://doi.org/10.1556/AGeol. 47.2004.2-3.3

Cambel B, Shcherbak NP, Kamenický L, Bartnicky JN, Veselský J (1977) Some results of geochronology of the crystalline complexes of the Western Carpathians on the basis of U-Th-Pb method. Geol Zbor Geol Carpath 28:243-259 (In Russian with English abstract)

Cambel B, Bagdasaryan GP, Gukasyan RC, Veselský J (1989) Rb-Sr geochronology of leucocratic granitoid rocks from the Spišskogemerské rudohorie Mts. and Veporicum. Geol Zbor Geol Carpath 40:323-332

Cassinis G, Perotti CR, Ronchi A (2012) Permian continental basins in the Southern Alps (Italy) and Peri-Mediterranean correlations. Int J Earth Sci 101:129-157. https://doi.org/10.1007/ s00531-011-0642-6

Clemens JD, Holloway JR, White AJR (1986) Origin of an A-type granite: experimental constraints. Am Miner 71:317-324

Collins WJ, Beams SD, White AJR, Chappell BW (1982) Nature and origin of A-type granites with particular reference to southeastern Australia. Contrib Mineral Petrol 80(2):189-200

Creaser RA, Price RC, Wormald RJ (1991) A-type granites revised: assessment of a residual-source model. Geology 19(2):163166. https://doi.org/10.1130/0091-7613(1991)019\%3c0163: ATGRAO\%3e2.3.CO;2

Dahlquist JA, Alasino PH, Bello C (2014) Devonian F-rich peraluminous A-type magmatism in the proto-Andean foreland (Sierras Pampeanas, Argentina): geochemical constraints and petrogenesis from the western-central region of the Achala batholith. Miner Petrol 108:391-417. https://doi.org/10.1007/s00710-013-0308-0

De La Roche H, Leterrier J, Grandclaude P, Marchal M (1980) A classification of volcanic and plutonic rocks using $R_{1} R_{2}$-diagram and major-element analyses: its relationships with current nomenclature. Chem Geol 29:183-210. https://doi.org/10.1016/00092541(80)90020-0

Demko R, Hraško L’ (2013) Rhyolite body Gregová near the Telgárt village (Western Carpathians). Miner Slov 45:161-174 (In Slovak with English summary)

Denèle Y, Paquette J-L, Olivier P, Barbey P (2012) Permian granites in the Pyrenees: the Aya pluton (Basque Country). Terra Nova 24:105-113. https://doi.org/10.1111/j.1365-3121.2011.01043.x

Eby GN (1990) The A-type granitoids; a review of their occurrence and chemical characteristics and speculations on their petrogenesis. Lithos 26:115-134. https://doi.org/10.1016/0024-4937(90) 90043-Z

Eby GN (1992) Chemical subdivision of the A-type granitoids: petrogenetic and tectonic implications. Geology 20:641-644. https:// doi.org/10.1130/0091-7613(1992)020\%3c0641:CSOTAT\%3e2.3. $\mathrm{CO} ; 2$

Filippi M, Zanoni D, Lardeaux J-M, Spalla MI, Gosso G (2020) Evidence of Tethyan continental break-up and Alpine collision in the Argentera-Mercantour Massif. Western Alps Lithos 372373:105653. https://doi.org/10.1016/j.lithos.2020.105653
Finger F, Broska I (1999) The Gemeric S-type granites in southeastern Slovakia: Late Paleozoic or Alpine intrusions? Evidence from electron-microprobe dating of monazite. Schweiz Mineral Petrogr Mitt 79:439-443

Finger F, Broska I, Haunschmid B, Hraško L, Kohút M, Krenn E, Petrík I, Riegler G, Uher P (2003) Electron microprobe dating of monazites from Western Carpathian basement granitoids: plutonic evidence for an important Permian rifting event subsequent to Variscan crustal anatexis. Int J Earth Sci 92:86-98. https://doi. org/10.1007/s00531-002-0300-0

Frost CD, Frost BR (1997) Reduced rapakivi-type granites: The tholeiite connection. Geology 25:647-650. https://doi.org/10.1130/ 0091-7613(1997)025\%3c0647:RRTGTT\%3e2.3.CO;2

Frost CD, Frost BR (2011) On ferroan (A-type) granitoids: their compositional variability and modes of origin. J Pet 52:39-53. https://doi.org/10.1093/petrology/egq070

Frost BR, Barnes CG, Collins WJ, Arculus RJ, Ellis DJ, Frost CD (2001) A geochemical classification for granitic rocks. J Pet 42:2033-2048

Gao P, Garcia-Arias M, Chen Y-X, Yhao Z-F (2020) Origin of peraluminous A-type granites from appropriate sources at moderate to low pressures and high temperatures. Lithos 352-353:105287. https://doi.org/10.1016/j.lithos.2019.105287

Grebennikov AV (2014) A-type granites and related rocks: petrogenesis and classification. Russ Geol Geophys 55:1354-1366. https://doi. org/10.1016/j.rgg.2014.10.011

Gregory RT, Taylor HP Jr (1981) An oxygen isotope profile in a section of Cretaceous oceanic crust, Samail ophiolite, Oman: Evidence for $\mathrm{d}^{18} \mathrm{O}$ buffering of the oceans by deep $(>5 \mathrm{~km})$ seawaterhydrothermal circulation at mid-ocean ridges. J Geophys Res. https://doi.org/10.1029/JB086iB04p02737

Gyalog L, Horváth I (2004) Geology of the Velence Hills and Balatonfő. Geological Institute of Hungary, Hungary, p 316

Huang H-Q, Li X-H, Li W-X, Li Z-X (2011) Formation of high $\delta^{18} \mathrm{O}$ fayalite-bearing A-type granite by high-temperature melting of granulitic metasedimentary rocks, southern China. Geology 39:903-906. https://doi.org/10.1130/G32080.1

Huraiová M, Paquette J-L, Konečný P, Gannoun A-M, Hurai V (2017) Geochemistry, mineralogy, and zircon $\mathrm{U}-\mathrm{Pb}-\mathrm{Hf}$ isotopes in peraluminous A-type granite xenoliths in Pliocene-Pleistocene basalts of northern Pannonian Basin (Slovakia). Contrib Miner Pet 172:59. https://doi.org/10.1007/s00410-017-1379-4

Huraiová M, Konečný P, Hurai V (2019) Niobium Mineralogy of Pliocene $\mathrm{A}_{1}$-Type Granite of the Carpathian Back-Arc Basin. Central Europe Minerals 9:488. https://doi.org/10.3390/min9080488

Isozaki Y (2009) Illawara Reversal: the fingerprint of superplume that triggered Pangean breakup and the end-Guadalupian (Permian) mass extension. Gondwana Res 15:421-432. https://doi.org/10. 1016/j.gr.2008.12.007

Janoušek V, Moyen J-F, Martin H, Erban V, Farrow C (2016) Geochemical modelling of igneous processes: principles and recipes in $\mathrm{R}$ language. Bringing the power of $\mathrm{R}$ to a geochemical community. Springer, Berlin, p 346. https://doi.org/10.1007/ 978-3-662-46792-3

Kaur P, Chaudhri N, Hofmann AW, Raczek I, Okrusch M, Skora S, Baumgartner LP (2012) Two-stage, extreme albitization of A-type granites from Rajasthan, NW India. J Petrol 53:919-948. https://doi.org/10.1093/petrology/egs003

Kędzior A, Budzyń B, Popa ME, Siwecki T (2020) Monazite U-Thtotal $\mathrm{Pb}$ age constraints on an early Permian volcanic event in the South Carpathians, Romania. Geol Carpath 71:73-82. https://doi. org/10.31577/GeolCarp.71.1.6

King PL, White AJR, Chappell BW, Allen CM (1997) Characterization and Origin of Aluminous A-type Granites from the Lachlan Fold Belt, Southeastern Australia. J Pet 38:371-391. https://doi.org/ 10.1093/petroj/38.3.371 
Klötzli US, Sinigoi S, Quick JE, Demarchi G, Tassinari CCG, Sato K, Günes Z (2014) Duration of igneous activity in the Sesia Magmatic System and implications for high-temperature metamorphism in the Ivrea-Verbano deep crust. Lithos 206-207:19-33. https://doi.org/10.1016/j.lithos.2014.07.020

Knoll T, Schuster R, Huet B, Mali H, Onuk P, Horschinegg M, Ertl A, Giester G (2018) Spodumene pegmatites and related leucogranites from the Austroalpine Unit (Eastern Alps, Central Europe): field relations, petrography, geochemistry, and geochronology. Can Mineral 56:489-528. https://doi.org/10.3749/canmin.17000 92

Kohút M (2014) Granitic rocks - windows to crustal evolution during the Phanerozoic in the Western Carpathians. In: Beqiraj A, Uta A (eds) Proceedings XX congress of the Carpathian-Balkan Geological Association, special issue, 2/2014. Tirana, Albania, pp 192-195

Kohút M, Nabelek PI (2008) Geochemical and isotopic (Sr, Nd and O) constraints on sources for Variscan granites in the Western Carpathians: implications for crustal structure and tectonics. J Geosci 53:307-322. https://doi.org/10.3190/jgeosci.033

Kohút M, Recio C (2002) Sulphur isotopes of selected Hercynian granitic and surrounding rocks from the Western Carpathians (Slovakia). Geol Carpath 53:3-13

Kohút M, Stein H (2005) Re-Os molybdenite dating of graniterelated Sn-W-Mo mineralization at Hnilec, Gemeric Superunit, Slovakia. Miner Pet 85:117-129. https://doi.org/10.1007/ s00710-005-0082-8

Kohút M, Kovach VP, Kotov AB, Salnikova EB, Savatenkov VM (1999) Sr and Nd isotope geochemistry of Hercynian granitic rocks from the Western Carpathians: implications for granite genesis and crustal evolution. Geol Carpath 50:477-487

Kohút M, Trubač J, Novotný L, Ackerman L, Demko R, Bartalský B, Erban V (2013) Geology and Re-Os molybdenite geochronology of the Kurišková U-Mo deposit (Western Carpathians, Slovakia). J Geosci 58:275-286. https://doi.org/10.3190/jgeosci.150

Konopelko D, Biske G, Seltmann R, Eklund O, Belyatsky B (2007) Hercynian post-collisional A-type granites of the Kokshaal Range, Southern Tien Shan, Kyrgyzstan. Lithos 97:140-160. https://doi.org/10.1016/j.lithos.2006.12.005

Korikovsky SP, Putiš M, Zakariadze GS, Ďurovič V (1995) Alpine anchimetamorphism of the Infratatricum cover, Western Carpathians: Composition of authigenic and detrical muscovitephengite as an indicator of the metamorphic grade. Petrology 3:577-591

Kotov AV, Miko O, Putiš M, Korikovsky SP, Salnikova YV, Kovach VP, Yakovleva SZ, Bereznaya NG, Král J, Krist E (1996) U/Pb dating of zircons of postorogenic acid metavolcanics: a record of Permian-Triassic taphrogeny of the West-Carpathian basement. Geol Carpath 47:73-79

Kovách A, Svingor E, Grecula P (1986) Rb-Sr isotopic ages of granitoid rocks from the Spišsko-gemerské rudohorie Mts. Miner Slov $18: 1-14$

Kozur H (1991) The evolution of the Meliata-Hallstatt ocean and its significance for the early evolution of the Eastern Alps and Western Carpathians. Palaeogeogr Palaeoclimatol Palaeoecol 83:109-135. https://doi.org/10.1016/0031-0182(91)90132-B

Kubiš M, Broska I (2010) The granite system near Betliar village (Gemeric Superunit, Western Carpathians): evolution of a composite silicic reservoir. J Geosci 55:131-148. https://doi.org/10. 3190/jgeosci.066

Kunz BE, Manzotti P, von Niederhäusern B, Engli M, Darling JR, Giuntoni F, Lenari P (2018) Permian high-temperature metamorphism in the Western Alps (NW Italy). Int J Earth Sci 107:203229. https://doi.org/10.1007/s00531-017-1485-6
Larionov AN, Andreichev VA, Gee DG (2004) The Vendian alkaline igneous suite of northern Timan: ion microprobe $\mathrm{U}-\mathrm{Pb}$ zircon ages of gabbros and syenite. Geol Soc London Mem 30:69-74

Lelkes-Felvári G, Klötzli U (2004) Zircon geochronology of the "Kékkút quartz porphyry“, Balaton Highland, Transdanubian Central Range, Hungary. Acta Geol Hung 47:139-149

Litvinovsky BA, Ye V, Eyal M, Eyal Y (2021) The role of mantle and the ancient continental crust in the generation of post-collisional high-K calc-alkaline and alkaline granites, with main reference to the Arabian-Nubian Shield. Lithos 388-389:106049. https:// doi.org/10.1016/j.lithos.2021.106049

Loiselle MC, Wones DR (1979) Characteristics and origin of anorogenic granites. Ann Meet Geol Soc Amer Assoc Soc 11:468

Lu J, Zhang Ch, Liu D (2020) Geochronological, geochemical and Sr$\mathrm{Nd}-\mathrm{Hf}$ isotopic studies of the A-type granites and adakitic granodiorites in Western Junggar: Petrogenesis and tectonic implications. Minerals 10:397. https://doi.org/10.3390/min10050397

Ludwig KR (2005a) SQUID 1.12 A User's Manual. A Geochronological Toolkit for Microsoft Excel. Berkeley Geochronology Center Spec Publ, pp 1-22

Ludwig KR (2005b) User's Manual for ISOPLOT/Ex 3.22. A geochronological toolkit for Microsoft Excel. Berkeley Geochronology Center Spec Publ, pp 1-71

Macek J, Cambel B, Kamenický L, Petrík I (1982) Documentation and basic characteristics of granitoid rock samples of the West Carpathians. Geol Zbor Geol Carpath 33:601-621

Magna T, Janoušek V, Kohút M, Oberli F, Wiechert U (2010) Fingerprinting sources of orogenic plutonic rocks from Variscan belt with lithium isotopes and possible link to subduction-related origin of some A-type granites. Chem Geol 274:94-107. https:// doi.org/10.1016/j.chemgeo.2010.03.020

Marocchi M, Morelli C, Mair V, Klötzli U, Bargossi GM (2008) Evolution of large silicic magma systems: new U-Pb zircon data on the NW Permian Athesian volcanic group (Southern Alps, Italy). J Geol 116:480-498. https://doi.org/10.1086/590135

Martin RF (2006) A-type granites of crustal origin ultimately result from open-system fenitization-type reactions in an extensional environment. Lithos 91:125-136. https://doi.org/10.1016/j.lithos. 2006.03.012

Morales Cámera MM, Dahlquist JA, Ramacciotti CD, Galindo C, Basei MAS, Zandomeni PS, Grande MM (2018) The strongly peraluminous A-type granites of the Characato suite (Achala batholith), Sierras Pampeanas, Argentina: Evidence of Devonian-Carboniferous crustal reworking. J S Am Earth Sci 88:551-567. https:// doi.org/10.1016/j.jsames.2018.09.008

Morelli C, Marocchi M, Moretti A, Bargossi GM, Gasparotto G, De Waele B, Klötzli U, Mair V (2012) Volcanic stratigraphy and radiometric age constraints at the northern margin of a megacaldera system: Athesian Volcanic Group (Southern Alps, Italy). GeoActa 11:51-67

Muttoni G, Gaetani M, Kent DV, Sciunnach D, Angiolini L, Berra F, Garzanti E, Mattei M, Zanchi A (2009) Opening of the NeoTethys Ocean and the Pangea B to Pangea A transformation during the Permian. GeoArabia 14:17-47

Nikishin AM, Ziegler PA, Abbott D, Brunet M-F, Cloetingh S (2002) Permo-Triassic intraplate magmatism and rifting in Eurasia: implications for mantle plumes and mantle dynamics. Tectonophysics 351:3-39. https://doi.org/10.1016/S0040-1951(02) 00123-3

Ondrejka M, Broska I, Uher P (2015) The late magmatic to subsolidus $\mathrm{T}-\mathrm{fO}_{2}$ evolution of the Lower Triassic A- type rhyolites (Silicic Superunit, Western Carpathians, Slovakia): Fe-Ti oxythermometry and petrological implications. Acta Geol Slov 7:51-61

Ondrejka M, Bačík P, Sobocký T, Uher P, Škoda R, Mikuš T, Luptáková J, Konečný P (2018a) Minerals of the rhabdophane group and the alunite supergroup in microgranite: products of 
low-temperature alteration in a highly acidic environment from the Velence Hills, Hungary. Mineral Mag 82:1277-1300. https:// doi.org/10.1180/mgm.2018.137

Ondrejka M, Li X-H, Vojtko R, Putiš M, Uher P, Sobocký T (2018b) Permian A-type rhyolites of the Muráň Nappe, Inner Western Carpathians, Slovakia: in-situ zircon U-Pb SIMS ages and tectonic setting. Geol Carpath 69:187-198. https://doi.org/10.1515/ geoca-2018-0011

Pană DI, Heaman LM, Creaser RA, Erdmer P (2002) Pre-Alpine crust in the Apuseni Mountains, Romania: insights from Sm-Nd and U-Pb data. J Geol 110:341-354

Patiño Douce AE (1997) Generation of metaluminous A-type granites by low-pressure melting of calc-alkaline granitoids. Geology 25:743-746. https://doi.org/10.1130/0091-7613(1997)025\% 3c0743:GOMATG\%3e2.3.CO;2

Pelech O, Vozárová A, Uher P, Petrík I, Plašienka D, Šarinová K, Rodionov N (2017) Late Permian volcanic dykes in the crystalline basement of the Považský Inovec Mts. (Western Carpathians): U-Th-Pb SHRIMP and monazite chemical dating. Geol Carpath 68(6):530-542. https://doi.org/10.1515/geoca-2017-0035

Petrík I (2001) Permian and younger mildly alkalic granites. In: Petrík I, Kohút M, Broska I (eds) Granitic plutonism of the Western Carpathians, Guide book to Eurogranites 2001. Publishing House of the Slovak Academy of Sciences, Bratislava, Veda, pp 30-31

Petrík I, Broska I, Uher P (1994) Evolution of the Western Carpathian granite magmatism, age, source rocks, geotectonic setting and relation to the Variscan structure. Geol Carpath 45:365-371

Petrík I, Broska I, Bezák V, Uher P (1995) The Hrončok (Western Carpathians) type granite: a Hercynian A-type granite in shear zone. Miner Slov 27:351-364 (In Slovak with English summary)

Peytcheva I, von Quadt A, Titorenkova R, Zidarov N, Tarassova E (2005) Skrut granitoids from Belassitsa Mountain, SW Bulgaria: Constraints from isotope-geochronological and geochemical zircon data. Proc Jubil Intern Conf Bulg Gel Soc, Sofia, pp 109-112

Plašienka D, Grecula P, Putiš M, Kováč M, Hovorka D (1997) Evolution and structure of the Western Carpathians: an overview. In: Grecula P, Hovorka D, Putiš M (eds) Geological evolution of the Western Carpathians. Miner Slov Monogr, Bratislava, pp 1-24

Poller U, Broska I, Finger F, Uher P, Janák M (2000) Permian age of Gemeric granites constrained by single zircon and EMPA monazite dating. Miner Slov 32:189-190

Poller U, Uher P, Broska I, Plašienka D, Janák M (2002) First PermianEarly Triassic ages for tin bearing granites from the Gemeric unit (Western Carpathians, Slovakia): connection to the postcollisional extension of the Variscan orogen and S-type granite magmatism. Terra Nova 14:41-48. https://doi.org/10.1046/j. 1365-3121.2002.00385.x

Pupin J-P (1980) Zircon and granite petrology. Contrib Miner Pet 73:207-220. https://doi.org/10.1007/BF00381441

Pupin J-P (1992) Les zircons des granites océaniques et continentaux: couplage typologie-géochimie des éléments en races. Bull Soc Géol France 163:495-507

Putiš M, Filová I, Korikovsky SP, Kotov AB, Madarás J (1997) Layered metaigneous complex of the Veporic basement with features of the Variscan and Alpine thrust tectonics (the Western Carpathians). In: Grecula P, Hovorka D, Putiš M (eds) Geological evolution of the Western Carpathians. Miner Slov Monogr, Bratislava. pp 175-196

Putiš M, Kotov AB, Uher P, Salnikova E, Korikovsky SP (2000) Triassic age of the Hrončok pre-orogenic A-type granite related to continental rifting: a new result of U-Pb isotope dating (Western Carpathians). Geol Carpath 51:59-66

Putiš M, Li J, Ružička P, Ling X, Nemec O (2016) U/Pb SIMS zircon dating of a rhyolite intercalation in Permian siliciclastics as well as a rhyodacite dyke in micaschists (Infratatricum, W. Carpathians). Miner Slov 48:135-144
Putiš M, Li X-H, Yang YH, Li Q-L, Nemec O, Ling X, Koller F, Balen D (2018) Permian pyroxenite dykes in harzburgite with signatures of the mantle, subduction channel and accretionary wedge evolution (Austroalpine Unit, Eastern Alps). Lithos 314-315:165-186. https://doi.org/10.1016/j.lithos.2018.05.030

Putiš M, Koller F, Li X-H, Li Q-L, Larionov A, Siman P, Ondrejka M, Uher P, Németh Z, Ružička P, Nemec O (2019a) Geochronology of Permian-Triassic tectono-magmatic events from the Inner Western Carpathian and Austroalpine units. In: Proceedings of the Geol Carpath 70, Earth Sci Inst SAS, Bratislava, pp 119-122

Putiš M, Soták J, Li Q-L, Ondrejka M, Li X-H, Hu Z, Ling X, Nemec O, Németh Z, Ružička P (2019b) Origin and age determination of the Neotethys Meliata Basin ophiolite fragments in the Late Jurassic-Early Cretaceous accretionary wedge mélange (Inner Western Carpathians, Slovakia). Minerals 9:652. https://doi.org/ $10.3390 / \min 9110652$

Radvanec M, Grecula P (2016) Geotectonic and metallogenetic evolution of Gemericum (Inner Western Carpathians) from Ordovician to Jurassic. Miner Slov 48:105-118

Radvanec M, Konečný P, Ondrejka M, Putiš M, Uher P, Németh Z (2009) The Gemeric granites as an indicator of the crustal extension above the Late-Variscan subduction zone and during the Early Alpine riftogenesis (Western Carpathians): an interpretation from the monazite and zircon ages dated by CHIME and SHRIMP methods. Miner Slov 41:381-394 (In Slovak with English abstract and summary)

Rudnick RL, Gao S (2003) The composition of the continental crust. In: Rudnick RL (ed) The crust. Elsevier, Amsterdam, pp 1-64

Salnikova EB, Sergeev SA, Kotov AB (1998) U-Pb zircon dating of granulite metamorphism in the Sludyanskiy Complex, Eastern Siberia. Gondwana Res 1:195-205

Seghedi I, Bojar A-V, Downes H, Roşu E, Tonarini S, Mason P (2007) Generation of normal and adakite-like calc-alkaline magmas in a non-subductional environment: $\mathrm{An} \mathrm{Sr}-\mathrm{O}-\mathrm{H}$ isotopic study of the Apuseni Mountains neogene magmatic province, Romania. Chem Geol 245:70-88. https://doi.org/10.1016/j.chemgeo.2007. 07.027

Sharp ZD (1990) A laser-based microanalytical method for the in situ determination of oxygen isotope ratios of silicates and oxides. Geochim Cosmochim Acta 54:1353-1357. https://doi.org/10. 1016/0016-7037(90)90160-M

Shellnutt JG, Zhou M-F (2007) Permian peralkaline, peraluminous and metaluminous A-type granites in the Panxi district, SW China: their relationship to the Emeishan mantle plume. Chem Geol 243:286-316. https://doi.org/10.1016/j.chemgeo.2007.05.022

Sinigoi S, Quick JE, Demarchi G, Klötzli U (2011) The role of crustal fertility in the generation of large silicic magmatic systems triggered by intrusion of mantle magma in the deep crust. Contrib Mineral Petrol 162:691-707. https://doi.org/10.1007/ s00410-011-0619-2

Sinigoi S, Quick JE, Demarchi G, Klötzli U (2016) Production of hybrid granitic magma at the advancing front of basaltic underplating: Inferences from the Sesia Magmatic System (southwestern Alps, Italy). Lithos 252-253:109-122. https://doi.org/ 10.1016/j.lithos.2016.02.018

Sobocký T, Ondrejka M, Uher P, Mikuš T, Konečný P (2020) Monazite-group minerals and xenotime-(Y) in A-type granitic rocks: chemical composition and in-situ Th-U-total Pb EPMA dating (Velence Hills, Hungary). Acta Geol Slov 12:89-106

Spišiak J, Vetráková L, Chew D, Ferenc Š, Mikuš T, Šimonová V, Bačík P (2018) Petrology and dating of the Permian lamprophyres from the Malá Fatra Mts. (Western Carpathians, Slovakia). Geol Carpath 69:453-466. https://doi.org/10.1515/geoca-2018-0026

Spišiak J, Vetráková L, Mikuš M, Chew D, Ferenc Š, Šimonová V, Siman P (2019) Mineralogy and geochronology of calc-alkaline 
lamprophyres from the Nízke Tatry Mts. crystalline complex (Western Carpathians). Miner Slov 51:61-78

Stacey JS, Kramers JD (1975) Approximation of terrestrial lead isotope evolution by a two-stage model. Earth Planet Sci Lett 26:207221. https://doi.org/10.1016/0012-821X(75)90088-6

Steiger RH, Jäger E (1977) Subcommission on geochronology: convention on the use of decay constants in geo- and cosmochronology. Earth Planet Sci Lett 36:359-362. https://doi.org/10.1016/0012821X(77)90060-7

Steiger RH, Bickel RA, Meier M (1993) Conventional U-Pb dating of single fragments of zircon for petrogenetic studies of Phanerozoic granitoids. Earth Planet Sci Lett 115:197-209. https://doi. org/10.1016/0012-821X(93)90222-U

Sun Y, Ma C, Liu Y, She Z (2011) Geochronological and geochemical constraints on the petrogenesis of Late Triassic aluminous A-type granites in southeast China. J Asian Earth Sci 42:1117-1131. https://doi.org/10.1016/j.jseaes.2011.06.007

Szemerédi M, Lukács R, Varga A, Dunkl I, Józsa S, Tatu M, PálMolnár E, Szepesi J, Guillong M, Szakmány G, Harangi S (2020a) Permian felsic volcanic rocks in the Pannonian Basin (Hungary): new petrographic, geochemical, and geochronological results. Int J Earth Sci 109:101-125. https://doi.org/10.1007/ s00531-019-01791-x

Szemerédi M, Varga A, Szepesi J, Pál-Molnár E, Lukács R (2020b) Lavas or ignimbrites? Permian felsic volcanic rocks of the Tisza Mega-unit (SE Hungary) revisited: a petrographic study. Centr Eur Geol 63:1-18. https://doi.org/10.1556/24.2020.00003

Taylor HP Jr, Sheppard SMF (1986) Igneous Rocks: I. Processes of isotopic fractionation and isotopic systematics. Rev Mineral $16: 227-271$

Uher P, Broska I (1994) The Velence Mts. granitic rocks: geochemistry, mineralogy and comparison to Variscan Western Carpathian granitoids. Acta Geol Hung 37:45-66

Uher P, Broska I (1996) Post-orogenic Permian granitic rocks in the Western Carpathian-Pannonian area: geochemistry, mineralogy and evolution. Geol Carpath 47:311-321

Uher P, Gregor T (1992) The Turčok granite: product of post-orogenic A-type magmatism? Miner Slov 24:301-304 (Slovak with English abstract)

Uher P, Marschalko R (1993) Typology, zoning and geochemistry of zircon from main types of granitic and rhyolitic pebbles in conglomerates of the Pieniny Klippen Belt Cretaceous flysch (Western Slovak Segment, Western Carpathians). Geol Carpath 44:113-121

Uher P, Pushkarev Y (1994) Granitic pebbles of the Cretaceous flysch of the Pieniny Klippen Belt, Western Carpathians: U/Pb zircon ages. Geol Carpath 45:375-378

Uher P, Marschalko R, Martiny E, Puškelová L', Streško V (1994) Geochemical characterization of granitic rock pebbles from Cretaceous to Paleogene flysch of the Pieniny Klippen Belt. Geol Carpath 45:171-183

Uher P, Broska I, Ondrejka M (2002a) Permian to Triassic granitic and rhyolitic magmatism in the Western Carpathians: composition, evolution and origin. Geol Carpath Spec Iss 53:188-189

Uher P, Ondrejka M, Spišiak J, Broska I, Putiš M (2002b) Lower Triassic potassium-rich rhyolites of the Silicic Unit, Western Carpathians, Slovakia: geochemistry, mineralogy and genetic aspects. Geol Carpath 53:27-36

Uher P, Ondrejka M, Konečný P (2009) Magmatic and post-magmatic Y-REE-Th phosphate, silicate and Nb-Ta-Y-REE oxide minerals in A-type metagranite: an example from the Turčok Massif, the Western Carpathians, Slovakia. Miner Mag 73:1009-1025. https://doi.org/10.1180/minmag.2009.073.6.1009

Uher P, Ondrejka M, Bačík P, Broska I, Konečný P (2015) Britholite, monazite, REE carbonates, and calcite: Products of hydrothermal alteration of allanite and apatite in A-type granite from Stupné,
Western Carpathians, Slovakia. Lithos 236-237:212-225. https:// doi.org/10.1016/j.lithos.2015.09.005

Vai GB (2003) Development of the palaeography of Pangea from Late Carboniferous to Early Permian. Palaeogr Palaeoclimatol Palaeoecol 196:125-155. https://doi.org/10.1016/S0031-0182(03) 00316-X

Valley JW (2003) Oxygen isotopes in zircon. In: Hanchar JM, Hoskin PWO (eds) Zircon. Rev Miner Geochem 53:343-385

Valley JW, Kitchen N, Kohn MJ, Niendorf CR, Spicuzza MJ (1995) UWG-2, a garnet standard for oxygen isotope ratios: strategies for high precision and accuracy with laser heating. Geochim Cosmochim Acta 24:5223-5231. https://doi.org/10.1016/00167037(95)00386-X

Valley JW, Kinny PD, Schulze DJ, Spicuzza MJ (1998) Zircon megacrysts from kimberlite: oxygen isotope heterogeneity among mantle melts. Contrib Miner Pet 133:1-11. https://doi.org/10. 1007/s004100050432

Villaseñor G, Catlos EJ, Broska I, Kohút M, Hraško L, Aguilera K, Etzel T, Kyle JR, Stockli DF (2021) Evidence for widespread mid-Permian magmatic activity related to rifting following the Variscan orogeny (Western Carpathians). Lithos 390391:106083. https://doi.org/10.1016/j.lithos.2021.106083

Vozárová A, Šmelko M, Paderin I (2009) Permian single crystal U-Pb zircon age of the Rožňava Formation volcanites (Southern Gemeric Unit, Western Carpathians, Slovakia). Geol Carpath 60:439-448. https://doi.org/10.2478/v10096-009-0032-1

Vozárová A, Šmelko M, Paderin I, Larionov A (2012) Permian volcanics in the Northern Gemericum and Bôrka Nappe system: $\mathrm{U}-\mathrm{Pb}$ zircon dating and the implications for geodynamic evolution (Western Carpathians, Slovakia). Geol Carpath 63:191-200. https://doi.org/10.2478/v10096-012-0016-4

Vozárová A, Rodionov N, Vozár J, Lepekhina E, Šarinová K (2016) $\mathrm{U}-\mathrm{Pb}$ zircon ages from Permian volcanic rocks and tonalite of the Northern Veporicum (Western Carpathians). J Geosci 61:221237. https://doi.org/10.3190/jgeosci.215

Vozárová A, Larionov A, Šarinová K, Vd’ačný M, Lepekhina E, Vozár J, Lvov P (2018) Detrital zircons from the Hronicum Carboniferous-Permian sandstones (Western Carpathians, Slovakia): depositional age and provenance. Int J Earth Sci 107:1539-1555. https://doi.org/10.1007/s00531-017-1556-8

Vozárová A, Rodionov N, Šarinová K, Lepekhina E, Vozár J, Paderin I (2019) Detrital zircon U-Pb geochronology of PennsylvanianPermian sandstones from the Turnaicum and Meliaticum (Western Carpathians, Slovakia): provenance and tectonic implications. Int J Earth Sci 108:1793-1815. https://doi.org/10.1007/ s00531-019-01733-7

Vozárová A, Šarinová K, Rodionov N, Vozár J (2020) Zircon U-Pb geochronology from Permian rocks of the Tribeč Mts. (Western Carpathians, Slovakia). Geol Carpath 71:274-287. https://doi. org/10.31577/GeolCarp.71.3.6

Whalen JB, Hildebrand RS (2019) Trace element discrimination of arc, slab failure, and A-type granitic rocks. Lithos 348-349:105179. https://doi.org/10.1016/j.lithos.2019.105179

Whalen JB, Currie KL, Chappell BW (1987) A-type granites: geochemical characteristics, discrimination and petrogenesis. Contrib Mineral Petrol 95:407-419. https://doi.org/10.1007/BF004 02202

Wiedenbeck M, Allé P, Corfu F, Griffin WL, Meier M, Oberli F, Von Quadt A, Roddick JC, Spiegel W (1995) Three natural zircon standards for U-Th-Pb, Lu-Hf, trace element and REE analyses. Geostand Newslett 19:1-23. https://doi.org/10.1111/j.1751908X.1995.tb00147.x

Williams IS (1998) U-Th-Pb geochronology by ion microprobe. Applications in microanalytical techniques to understanding mineralizing processes. Rev Econ Geol 7:1-35 
Yuan S, Neubauer F, Liu Y, Genser J, Liu B, Yu S, Chang R, Guan Q (2020) Widespread Permian granite magmatism in Lower Austroalpine units: significance for Permian rifting in the Eastern Alps. Swiss J Geosci 113:18. https://doi.org/10.1186/ s00015-020-00371-5
Ziegler PA, Stampfli GM (2001) Late Palaeozoic-Mesozoic plate boundary reorganisation: collapse of the Variscan orogeny and opening of Neotethys. Nat Brescia 25:17-34 